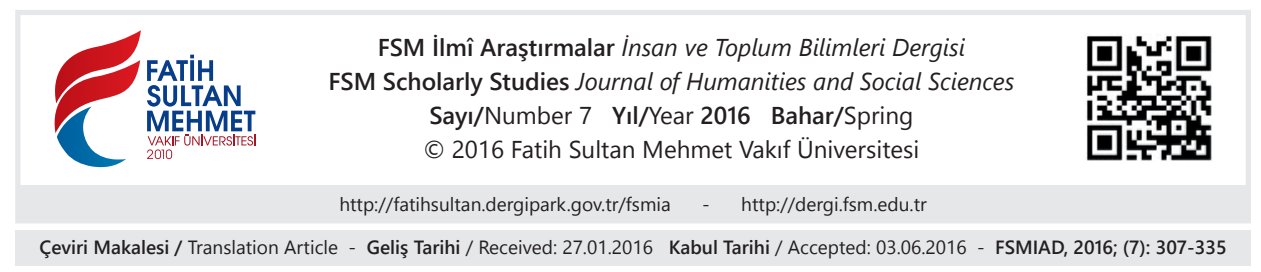

\title{
Modern İslamcılık Düşüncesinin Rakip Oksidentalizmleri: Necip Fazıl Kısakürek ve Nurettin Topçu'da Hıristiyanlık, Batı ve Çağdaşlık Anlayışı
}

\author{
Burhanettin Duran* \\ Cemil Aydın** \\ çeviren Demet Koçyiğit ***
}

\section{$\ddot{O} \mathbf{z}$}

Bu makale, çağdaş Müslüman düşünce tarihinde Oksidentalizm'in kökenlerini, muhtevasını, önerilerini ve geleneklerini tetkik etmek üzere Cumhuriyet dönemi Türkiyesinin iki etkili İslamcı aydını olan Necip Fazıl Kısakürek ve Nurettin Topçu'nun yazılarına odaklanacaktır. Kısakürek ve Topçu, Türkiye Cumhuriyeti’nin çağdaşlaşmacı laik hükumetinin seçilmiş bursiyerleri olarak Fransa'da eğitim gördüler. Fakat Türkiye’ye döndükten sonra Batı medeniyetini de Türkiye Cumhuriyeti'nin Batı'yı destekleyen fikri yapısını da sert bir şekilde eleştirerek, batılılaşmaya karşı İslamcı alternatifi destekleyenlere öncü oldular. Kısakürek ve Topçu Mısır ve Güney Asya'dan aydınlara daha çok odaklanan son dönem akademik İslamcılık yazınında göz ardı edilmiş isimleridir. Oysa Türkiye'de İslamcılık'ın gelişmesinde Kısakürek ve Topçu'nun yazıları oldukça önemlidir, zira onların fikirleri Seyyid Kutub ve Ebu'l-ala el-Mevdudî'nin 1970'lerde Türk diline yapılan tercümelerinin öncesinde derin ilgi görmüştür. Onların yazıları herhangi bir klasik İslami metinden ziyade savaş arası dönemin Fransız kültür hayatına daha yakın bir İslamcılık'a denk düşmektedir. Kısakürek ve Topçu'nun fikirleri Türkiye ve daha geniş manada Ortadoğu'nun çağdaş düşünce tarihinin güçlü oksidentalist söyleminden kesitler sunmaktadır ve bu fikirler ulus-devletin çağdaşlaşmacı bir döneminde Batı algısının karmaşık siyaseti hakkında bize pek çok şey öğretebilir.

Anahtar Kelimeler: Necip Fazıl Kısakürek, Nurettin Topçu, Oksidentalizm, İslamc1lik, Türkiye.

Bu makalenin İngilizce aslının künye bilgisi şu şekildedir: Cemil Aydın-Burhanettin Duran, "Competing Occidentalisms of Modern Islamist Thought: Necip Fazıl Kısakürek and Nurettin Topçu on Christianity, the West and Modernity", The Muslim World, 103:4, Wiley Online Library, 2013, pp. 479-500. (Makalenin tercümesini inceleme nezaketi gösteren Cemil Aydın'a teşekkür ederim. [Çev.])

* Prof. Dr., İstanbul Şehir Üniversitesi İnsan ve Toplum Bilimleri Fakültesi Siyaset Bilimi ve Uluslararası İlişkiler Bölümü, İstanbul/Türkiye, burhanettinduran@sehir.edu.tr

** Doç. Dr., The University of North Carolina at Chapel Hill, , Chapel Hill, North Carolina/USA, caydin@email.unc.edu

*** Doktora öğrencisi, Fatih Sultan Mehmet Vakıf Üniversitesi Sosyal Bilimler Enstitüsü Türk Dili ve Edebiyatı Bölümü, İstanbul/Türkiye, demetkocyigit1@gmail.com 


\title{
Competing Occidentalisms of Modern Islamist Thought: Necip Fazıl Kısakürek and Nurettin Topçu on Christianity, the West and Modernity
}

\begin{abstract}
This article will focus on the writings of two influential Islamist intellectuals of Republican era Turkey, namely Necip Fazıl Kısakürek and Nurettin Topçu, to examine the origins, content, appeal and legacy of Occidentalism in modern Muslim intellectual history. Both K1sakürek and Topçu were educated in France, as recipients of prestigious scholarships from the secular modernizing government of the Republic of Turkey. Upon their return to Turkey, however, they became leading proponents of Islamist alternative to westernization, harshly criticizing the pro-Western intellectual foundations of the Turkish Republic as well as Western civilization itself. Kısakürek and Topçu are neglected names in the recent literature on Islamism, which focuses more on the intellectuals from Egypt and South Asia. Yet, for the development of Islamism in Turkey, the writings of Kisakürek and Topçu were essential and occurred prior to the translations of Sayyed Qutb and Abu'l Ala Mawdudi into Turkish language in the 1970s. Their writings represent an Islamism that is more familiar with French intellectual life of the interwar era than any classical Islamic texts. Ideas of Kısakürek and Topçu represent the powerful occidentalist strands in modern intellectual history of Turkey and broader Middle East and can teach us a lot about the politics of the images of the West in an era of modernizing nation-states.
\end{abstract}

Keywords: Necip Fazıl Kısakürek, Nurettin Topçu, Occidentalism, Islamism, Turkey. 
Hayatın, düzenin ve Batı toplumunun kültürünün önemli her hususiyeti, olağanüstü bir buhran hâlindedir. Vücudu ve akl hastadır; ve vücudunda ne sızlamayan bir tek noktası ne de tıkır tıkır işleyen bir sinir hücresi mevcuttur. ${ }^{l}$

\section{Giriş*}

Türkiye'nin son dönemde yükselen bölgesel gücü ve küresel etkisi Türk toplumunu; sadece Batı, Avrupa Birliği, Amerika değil, diğer Müslüman çoğunluklu ülkelere dair vizyon ve siyasi yaklaşımında daha özgüvenli hâle getirmiştir. Türk vatandaşlarının çoğunluğu şimdilerde Müslüman kimlikleriyle gurur duymakta ve aynı zamanda Türkiye'nin Avrupa Birliği üyeliğini desteklemektedir. Avrupa Birliği'nin normatif değerleri ile kendi inançları, gelenekleri veya kültürleri arasında ciddi bir sorun olabileceğini tahmin etmemektedirler. Yine de, "Batı" şeklinde adlandırılan tahayyülî bütüne bu kendine güvenen yeni Türk siyasi bakış1 çağdaşlık, Batı medeniyeti ve Müslüman kimliği hakkındaki iki yüz yıllık tartışmaları kesin olarak ortadan kaldırmış değildir. Gerek Amerika'nın Müslümanlara yönelik siyasi tutumları ve gerekse Avrupa Birliği hususunda görülen çağdaş tartışmalarda Türk ve Müslüman kimliğinin Batı tarafından “öteki” olarak algılandığ1 köklü imajın izlerini görmek mümkündür. Bu sebeple, çağdaş Türk düşüncesinde Batı ve Oksidentalizm'le ilgili söylemlerin görüldüğü entelektüel tarihi, özellikle Cumhuriyet'in önde gelen İslamcı aydınlarının yazılarından yola çıkarak anlamak önem arz etmektedir. İslamcı oksidentalist yaklaşımın Batı algıs1 tahkik edilmeden, bu aydınların kendilerini nasıl algıladığının ve İslami kimliği canlandırmak üzere gerçekleştirdikleri arayışın anlaşılması mümkün değildir. Bunun anlaş1labilmesi, günümüz Türk siyaseti ve kültüründe "Batı" ile ilgili sorunun süregelen önemini, eskiliğini ve münasebetini vurgulayacaktır.

$\mathrm{Bu}$ makale, çağdaş Müslüman düşünce tarihinde Oksidentalizm'in kökenlerini, muhtevasını, önerilerini ve geleneklerini tetkik etmek üzere Cumhuriyet dönemi Türkiyesinin iki etkili İslamcı aydını olan Necip Fazıl Kısakürek ve Nurettin Topçu'nun yazılarına odaklanacaktır. Kısakürek ve Topçu, Türkiye Cumhuriyeti'nin çağdaşlaşmacı laik hükumetinin seçilmiş bursiyerleri olarak Fransa'da eğitim gördüler. Fakat Türkiye'ye döndükten sonra Batı medeniyetini de Türkiye Cumhuriyeti'nin Batı'yı destekleyen fikri yapısını da sert bir şekilde eleştirerek, batılılaşmaya karşı İslamcı alternatifi destekleyenlere öncü oldular. Kısakürek ve Topçu Mısır ve Güney Asya'dan aydınlara daha çok odaklanan son dönem

* Makalede yer alan doğrudan alıntılar Türkçe aslından aktarılmıştır. Dolaylı alıntılar ve aktarımlar için de Türkçe aslına uygun kelimeler tercih edilmiş, birebir tercümeden kaçınılmıştır. Bunun uygulanamadığı kısımlarda ise köşeli parantez içerisinde asıl metinlerden kelimeler ve ifadeler aktarılmıştır. (Çev. Notu) Öneri ve yorumları dolayısıyla Ümit Cizre'ye teşekkür ederiz.

1 Pitirim A. Sorokin, The Crisis of Our Age, Oxford, Oneworld, 1941, 1992, s. 13. 
akademik İslamcılık yazınında göz ardı edilmiş isimleridir. Oysa Türkiye'de İslamcılık'ın gelişmesinde Kısakürek ve Topçu'nun yazıları oldukça önemlidir, zira onların fikirleri Seyyid Kutub ve Ebu'l-ala el-Mevdudî’nin 1970'lerde Türk diline yapılan tercümelerinin öncesinde derin ilgi görmüştür. Onların yazıları herhangi bir klasik İslami metinden ziyade savaş arası dönemin Fransız kültür hayatına daha yakın bir İslamcılık'a denk düşmektedir. Kısakürek ve Topçu'nun fikirleri Türkiye ve daha geniş manada Ortadoğu'nun çağdaş düşünce tarihinin güçlü oksidentalist söyleminden kesitler sunmaktadır ve bu fikirler ulus-devletin çağdaşlaşmacı bir döneminde Batı algısının karmaşık siyaseti hakkında bize pek çok şey öğretebilir.

Çağdaş Türk tarihinin bu önemli iki İslamcı aydınına odaklanmadan önce, ilk olarak Oksidentalizm'in bir tanımını sunmalıyız: Oksidentalizm, Batı'nın “temel yapısı"nın "biçimsel bir algısı"dır. Carrier' in bahsettiği gibi “Oryantalizm ve Oksidentalizm' in özleştirilmeleri, gruplar arasındaki beklenmedik farklılıklardan kaynaklanmamaktadır, fakat bir özleştirme sürecinde meydana gelmektedir. $\mathrm{Bu}$ süreçte toplum içi ve toplumlar arasındaki siyasi ilişkiler bu toplumların temel özelliklerinin yorumunu ve yapısını şekillendirmektedir."2 Oksidentalizm'in bu tanımına ve Batı/İslam medeniyet ilişkilerinin temel bir okumasına göre, Kemalist, seküler ve solcu aydınların İslamcı özleştiricilikle çarpıcı birtakım benzerlikleri olan kendi Batı-özleştiricilik yorumları olduğu da ifade edilmelidir. Bir diğer ifadeyle, Kemalistlerin ve İslamcıların "Batı" algılarının ideolojik olarak çatışması, birçok benzer temaya rağmen, farklı oksidentalist yorumlar ortaya koymaktadır.

Türkiye'de tek parti döneminde (1932-1946), geçmişte İslami düşünce geleneğinin oluşmasına yardım eden ve bu geleneği sürdüren siyasi, sosyal ve kurumsal unsurlar (örneğin gazeteler, medreseler, hükumet gibi) Kemalist elit tarafından yıkıcı bir tavırla yasaklandı ya da yok edildi. Son dönem Osmanlı İmparatorluğu İslami düşünce geleneği 1930'ların ortalarına kadar bir yok olma tehlikesi içindeydi. Osmanlı İmparatorluğu'nun İkinci Meşrutiyet döneminin (1908-1918) 1920 ortalarındaki büyük seküler dönüşümünden kurtulan münferit İslamcıları sürgüne ya da sessizliğe zorlandıkları için düzenli bir siyasi ajandaya ya da etkin bir direnme programına sahip değildiler. Fakat 1930'ların sonunda ve 1940'ların başında Türkiye Cumhuriyeti'nin kültürel ve siyasi havasını değiştirecek yeni duyarlılıklar, argümanlar ve referanslar sunan, seküler Batı eğitimi almış olan İslamcı bir aydın grubu ortaya çıktı. Necip Fazıl Kısakürek ve Nurettin Topçu'nun her ikisi de İslamcılık'ın Cumhuriyet döneminin, temel amaçları Batı'nın Müslüman toplumlardaki kültürel ve emperyal hegemonyasını eleştir-

2 James G. Carrier, "Introduction", Occidentalism: Images of the West, ed. James G. Carrier, Oxford, Clarendon Press, 1995, s. 8. 
mek kadar Türkiye'deki Batıcı aydınların Avrupa-merkezci fikirlerine de karşılık vermek olan yeni neslini temsil etmektedir. Necip Fazıl Kısakürek (1904-1983) ve Nurettin Topçu (1909-1975) Sorbonne Üniversitesi’nde Batı Felsefesi okumak üzere genç Cumhuriyet tarafından Paris'e gönderilen öğrenciler arasındaydı. Topçu, felsefe doktorasını tamamlamış fakat Kısakürek eğitimini tamamlayamamıştır ve Eğitim Bakanlığı tarafından Türkiye'ye geri çağrılmıştır. Bu iki etkin İslamcı aydın çalışmalarının büyük bir kısmını İslami terimlere dayanan, Türk milletinin sorunlarını çözebilecek ideolojik bir sistem kurmaya ayırdılar ise de Batı, çağdaşlık ve Türkiye için öngördükleri İslami gelecek açısından birbirinden çok farklı bir algıya sahiptiler.

\section{Cumhuriyet Türkiye'sinde İslamcı Düşünce Geleneğinin Dirilişi}

Türk toplumu, çok partili siyaset sisteminin getirdiği (1946-1950) serbestleşmeyle rejimin sekülerleşme reformlarının zirvede olduğu dönem boyunca Türk nüfusunun bazı kesimleriyle olan bağlarını bir şekilde kaybetmemeyi başaran Sufi tarikatların ve toplulukların canlandıklarına şahit oldu. Tekke ve zaviyelerin 1925 'te kapatılmış olmasına rağmen Türkiye'deki tasavvuf ve halk İslam'1 direndi. ${ }^{3}$ Aslında İslami dirilişin liderleri büyük oranda Said-i Nursi gibi İkinci Meşrutiyet Dönemi (1908-1918)'nde hayatta kalan nadir İslamcılar ve Nakşibendilik gibi tarikatların şeyhleriydi. Cumhuriyet'te İslamcılık'ın canlanmasında Nakşibendilerin etkisi, Cumhuriyet'in ilk yıllarında medreselerin feshedilmesinden sonra hukuken yasaklanmış olmasına rağmen faaliyetlerini sürdürmeyi başaran Sufi ağının dini eğitim, manevi ilham ve eğitim sunmasından kaynaklanmaktadır. ${ }^{4}$ Örneğin, Kısakürek ve Topçu'nun her ikisi de Batı eğitimlerine nazaran Nakşibendi şeyhleri Abdülhakim Arvasi ve Abdülaziz Bekkine'den daha çok etkilenmişlerdir. ${ }^{5}$

İslamcı aydınların rolü yirminci yüzyılda ortaya çıkan yeni bir durumdu. Edward Shils'in ifade ettiği gibi, çağdaş aydınların esas siyasi görevleri bir "ülkü sunmaları ve bunun peşinde olmaları"dır. ${ }^{6}$ Aydın, ayrıca "her zaman değil ama

3 Howard A. Reed, "The Religious Life of Modern Turkish Muslims", Islam and the West, ed. Richard N. Frye, The Hague, Mouton\& Co, 1956, s. 138.

4 Hamid Algar, "The Naqshbandi Order in Republican Turkey," Islamic World Report 1/3 (1996), s. 62. Nakşibendiler ulemanın büyük kısmı göz önünde bulundurulmak kaydıyla, diğer Sufi tarikatlara nazaran dini ilimler çalışmasına her zaman daha ilgili olmuştur.

5 Bu iki şeyh Türkiye'de özellikle Kürt nüfusun yoğun olduğu güneydoğu bölgesinde etkin olan Nakşibendi tarikatının Halidiye koluna bağlıdır. Bu kol, Mevlana Halid'in öğretilerine bağlıdır ve politikacılar ve aydınlarla olan bağlantıları sayesinde etkisini cumhuriyete kadar ulaştıran Ahmed Ziyaüddin Gümüşhanevi tarafindan Osmanlı İmparatorluğu'nda temsil edilmiştir. Hayatı ve fikirleri için bkz.: Gümüşhanevi Ahmed Ziyaüddin: Hayatı-Eserleri-Tarikat Anlayışı ve Halidiyye Tarikatı, İstanbul, Seha, 1984.

6 Edward Shils, "Intellectuals", International Encyclopedia of the Social Sciences, New York, Macmillan, 1968, s. 414. 
genellikle bir eylem olan yeni kollektivite düşüncesi adına öne sürülen iddiaları meşrulaştırmanın, bundan sonra kültürel geleneklerin, geçmişin ihtişamının keşfedilmesi"nin esas aktörüydü. ${ }^{7}$

Fakat, Türkiye bağlamında şunu ifade etmek gerekir ki, "aydın" teriminin kullanımı hem Kemalistler hem de İslamcılar için sorunlu bir mevzudur. Vazife duygusuna verilen ehemmiyet nedeniyle, aydın, farklı ideolojik grupların sahip olmak için rekabet ve mücadele ettiği bir "ünvan" manası kazandı: Kendi görevini bütün yerleşik otoritelerle mücadele ederek 'kültür'ü müdafa etmekle ya da 'standartlar' 1 değersizleştirenlere karşı onların savunucuları olarak tanımlanabilir bir grup.["] "Entelijensiya" kendilerini bir vazifeye adayan ve toplumun karanlık köşelerini aydınlatmak ve uygarlaştırmayı bir yükümlülük olarak algılayan bir aydınlar grubu olarak akla gelmekteydi. Toplumu çağdaşlaştırma onların esas amaç ve yolları olarak düşünülmekteydi. ${ }^{9}$ Bu vazife duygusunu hem Kemalist zümre hem de İslamcılar paylaşıyor olmasına rağmen İslami bir söyleme dayananları İslamcı aydınlar olarak; seküler reformlar için ideolojik bir meşrulaştırmayı geliştirerek egemen güçlerin bir parçası haline gelen kişileri ise Kemalist entelijensiya olarak adlandırmaktayız.

1940'ların sonları ve 1950'lerde İslamcı aydınların düşüncelerinin rağbet kazanmasının hem Kemalist rejimin başarısızlıkları ve hem de, çelişkili olsa da, başarıları ile kısmen bağlantılı olması muhtemeldir. Mardin'in söz konusu ettiği üzere Kemalistlerin "akla ve kalbe sevimli gelen sosyal bir hayat felsefesi" intizam etmedeki başarısızlıkları İslami kural ve değerlerin ferdin ve daha geniş manada toplumun günlük hayatını şekillendirdiği bir toplum içinde ideolojik bir boşluk yaratt1. ${ }^{10}$ Kemalizm ne İslam'a rakip bir ideoloji oldu ne de İslam'a rakip olabilecek herhangi bir ideolojinin hayat bulmasını mümkün k1ldı. ${ }^{11}$

İslamcı aydınlar Kemalist modernleşmenin başarılarına da ayrıca kendi programları çerçevesinde sahiptiler: Cumhuriyet taraftarı İslamcı aydınlar, tek partili rejimden demokratik sisteme geçilirken İslami siyaset ve kültürel gelenekleri farklı bağlamlarda yeniden yapılandırmalarıyla, Türk modernleşme sürecinin bir parçası oldular. Bir kısım aydınların Kemalizm'in ideolojik ölçülerini kabul ede-

7 Edward Shils, "The Intellectuals in the Political Development of the New States", Political Development and Social Change, eds. Jason L. Finkle and Richard W. Gable, New York, John Wiley and Sons Inc, 1971, s. 258.

8 Ron Eyerman, Between Culture and Politics: Intellectuals in Modern Society, Cambridge, Polity Press, 1994, s. 23.

9 Ron Eyerman, Between Culture and Politics, s. 21.

10 Şerif Mardin, "Religion and Politics in Modern Turkey", Islam in the Political Process, ed. James P. Piscatori, Cambridge, Cambridge University Press, 1983, s. 155-6 ve Şerif Mardin, Türkiye'de Din ve Siyaset, İstanbul, İletişim, 1992, 2. bsk., s. 243.

11 Şerif Mardin, Din ve İdeoloji, İstanbul, İletişim, 1992, 5. bsk., s. 148-149. 
rek ve üreterek yeni rejimin oluşumuna katkıda bulunmaları gibi aydınların diğer kısmı da Kemalist rejim tarafından yok edilen kadim dini değerlerden oluşturulan alışılmışın dışında bir ideolojiyi savunarak siyasi muhalefet kanadına geçtiler.

İslam'ın yeniden etkin hâle gelmesinin bir diğer yönü de entelektüel faaliyetin Kemalist güçler tarafından siyasileştirilmesiydi. Reformları sayesinde devlet, Türk kültürünün temel fiiliyatını doğrudan yönetebiliyordu. Nitekim entelektüel faaliyetin her alanına, Batı medeniyetine bağımlı, seküler ahlâk anlayışına sahip, Müslüman çoğunluğun oluşturduğu toplumdan uzak bir toplum yaratmaya çalışan Kemalist "medeniyet dönüşümü" sürecinde siyasi ve ideolojik anlamlar yüklendi. ${ }^{12}$ Medeniyet söylemi, kültür ve çağdaşlaşmayı siyasi yöntem olarak benimseyen, hem Kemalist entelijensiya hem de İslamcı aydınlar oluşumu açısından oldukça önemli hâle geldi. ${ }^{13}$

On dokuzuncu yüzyılda Genç Osmanlılar'ın ellerinde İslam'ın ideolojileştirilmesinde araç olarak kullanılan gazetecilik ve edebiyat, İslamcı aydınlar da dahil Cumhuriyet dönemi aydınları tarafından siyasi fikirlerin ifade edilmesinde verimli bir zemin olmaya devam etti. Hem Necip Fazıl Kısakürek hem de Nurettin Topçu gazete yayımlama faaliyetinde etkin rol aldılar (özellikle Büyük Doğu ve Hareket) ve modern Türk edebiyatının farklı alanlarına katkıda bulundular.

\section{İslamcı Oksidentalizm ve Batı Karşısında Medeniyet Söylemi}

Cumhuriyet'in ilk dönemindeki köklü reformlara ek olarak, İslamcı aydınlar ilerleme ve çağdaşlaşmanın aksine İslam'ın Oryantalist tanımları şeklinde Avrupa'dan gelen fikri tartışmalara da karşılık veriyorlardı. Verdikleri karşılıkta, İslamcı aydınlar ilerlemeci ve çağdaş olarak değerlendirdikleri İslami geleneğin unsurlarını özenle seçerek vurgulamaktaydı. ${ }^{14}$ Batı ve çağdaşlaşmanın İslamcı ayrışması, çağdaşlaşma ve ilerlemeyle uyum gücü ile donatılan İslam'ın miras1nın eleştirel bir şekilde değerlendirilmesine imkân vermiş oldu. Türk milliyetçiliğinin Cumhuriyet dönemi öncesinde, Osmanlı İmparatorluğu'nun son üç asrında, aydınların İslam medeniyeti vurgusunda birincil amaçları Müslümanları sömürge hakimiyeti buhranından kurtaracak ve Osmanlı İmparatorluğu'nun hâkimiyetini savunacak yeterli fikri bilincin oluşumuna katkıda bulunmaktı.

12 Ertan Aydın, "Peculiarities of Turkish Revolutionary Ideology in the 1930s: The Ülkü Version of Kemalism, 1933-1936", Middle Eastern Studies 40, no. 5, 2004, s. 55-82.

13 1980-1990'ların Batı medeniyetini ve çağdaşlaşma düşüncesini sert bir dille eleştiren yeni nesil İslamcılar için bakınız: Binnaz Toprak, "Islamist Intellectuals: Revolt Against Industry and Technology", Turkey and the West: Changing Political and Cultural Identities, ed. Metin Heper, Ayşe Öncü ve Heinz Kramer, London, I. B. Tauris, 1993, s. 237-257.

14 Çağdaşlaşma ile ilgili bu önemli tutum için bkz.: Burhanettin Duran, Transformation of Islamist Political Thought in Turkey From the Empire to the Early Republic (1908-1960), Yayımlanmamış Doktora Tezi, Ankara, Bilkent Üniversitesi, 2001. 
Cumhuriyet dönemi aydınlarının yazılarında sunulan İslami Oksidentalizm'in en önemli özellikleri nelerdir? Her ne kadar İslamcı Oksidentalizm Batı ile ilgili genel olarak olumsuz bir söyleme sahipse de bu, resmin bütününü yansıtmamaktadır. Batı'nın üstünlüğünün incelenmesi Genç Osmanlılar'dan bu yana İslamc1 söylemlere merkez teşkil etmiştir. Batı'nın üstünlüğü meselesinin ve "Doğu" ya da "Müslüman Dünya"nın reddiyle ilişkili olarak çeşitli "Batının yükselişi”" hikâyelerinin kabulü açısından Kemalistler ve İslamcılar genel bir kanıyı paylaşmaktaydı. Kemalist aydınlar sıklıkla İslamcılar'ı Türk toplumunun kaçınılmaz ve gerekli olan batılılaşması ve çağdaşlaşmasına karşı olan geleneksel irticacılar olarak tasvir ettiler. Bu, İslamcılar'ın gerçek Batı algılarının tasvirinden ziyade ideolojik bir tartışma niteliğindeydi. Aslında İslamcılar asla Batı'yı reddeden olmadılar ve Kemalistler de asla Batı'nın saf taklitçileri olmadılar. Bir anlamda, Kemalizm ve İslamcılık'ın her ikisini de aynı bilgi evrenine ait olarak değerlendirebiliriz - biri Avrupa merkezli unsurlar olan çağdaş fikirler ve değerleri, kendi kültürel ve milli unsurlarına uygun hale getirmek kaydıyla çağdaşlaşma diline ve Batı'nın üstünlüğünün kabulüne dayanır. - Bu bağlamda, İslamcı aydınlar için, geniş ölçüde, oksidentalist bakışla kurgulanan Batı, hâkimiyeti, çağdaş zamanlarda İslam medeniyetinin tekrar canlanmasına hizmet eden tahayyülî bir varlık olagelmiştir.

“Batı” ve İslam'ın İslamcı özleştiriciliği büyük oranda, farklılık algısından kaynaklanmaktaydı. Bazen bu farklılık algısı, Lindstorm'un adlandırdığı gibi, "oto-oryantalizm, doğuya ait olanların kendi-söylemi” şeklini alacak kadar abartılabilmekteydi. "15 "İslam" ve "Batı", güçlü gerçeklikler olduğu fikrini uyandırmaya yatkınsa da, Müslüman ve Hıristiyan Avrupa toplumları arasındaki tarihi bağlar kadar her ikisinde de dikkate değer farklılıklar bulunmaktadır. Bununla beraber, medeniyet söylemleri, "Batı"y1 "İslam"la boy ölçüştüren belirli konulara ve bilgi kategorilerine odaklanmaktadır. Hatta bu söylemler içerisinde bu iki terimi birbirine tamamen zit olarak tanımlayanların büyük bir yekûn tuttuğunu görmekteyiz. Örneğin Batı, genellikle İslamcılar tarafindan tabiata hâkimiyeti ve teknolojik başarısına rağmen ahlâksız bir medeniyet olarak görülmektedir. Batı üzerine kaleme alınmış çoğu yazı Müslüman toplumlardaki aile ve inanç gücüyle kıyaslandı̆̆ında, Hıristiyanlık müesseselerinin ve ailenin mahvolmuş durumda olduğunu 1srarla belirtmektedir. Yine de bazen, Batı'daki ahlâki buhranı Hıristiyanlık'ın maneviyatını ihlal eden sekülerleşme ve sanayileşmeye mâl eden İslamcı yazılarda, Hıristiyanlık imajı olumludur. Konumunu ve siyasi sonuçlarını daha iyi anlamak için İslamcı edebiyattaki bu çeşitliliği tanımamız gerekmektedir.

15 Lamont Lindstrom, "Cargoism and Occidentalism", Occidentalism: Images of the West, ed. James G. Carrier, Oxford, Clarendon Press, 1995, s. 35. 


\section{Rakip Medeniyet Olarak Batı: Necip Fazıl Kısakürek}

Cumhuriyet Türkiye'sinde İslam'ın ideolojileştirilmesinin öncü kimliği Necip Fazıl Kısakürek'ti. ${ }^{16}$ İslam'ı insanlığın kurtuluşu için Müslüman mirasının canlanışının gücünü göstererek Kapitalizm ve Marksizm'e alternatif bir ideoloji olarak sundu. 1940'larda Kısakürek Türkiye'nin siyasi, kültürel ve sosyal problemlerine İslami çözümler öneren, bütüncül ve kapsamlı bir vizyona sahip olan Büyük Doğu isimli İslamcı formülünü sundu. Dahas1, ideolojik formülasyonunda, İslam, Batı olarak adlandırılan medeniyetin iki farklı unsuru olarak tanımladığı Kapitalizm ve Komünim'den daha üstün olarak görülmekteydi. Ayrıca Kısakürek, İkinci Meşrutiyet Dönemi İslamcıları tarafindan formüle edilen Batı/ medeniyet/çağdaşlık'ın iyi/maddî ve kötü/manevî özellikleri arasındaki farkları da gündemine aldı. Karmaşık bir metodu kullanarak, Batı'nın siyasi hâkimiyetine yol açan Batı ideolojilerinin ve değerlerinin hâlihazırda İslam'ın doğasında var olduğunu tartışabiliyordu.

Kısakürek II. Dünya Savaşı boyunca yazarak, dünyanın tecrübe ettiği hassas bir durumu olarak değerlendirdiği manevi buhranı vurguladı ve insanlık tarihinin bir sonucu olarak Batı medeniyetinde inancı sorguladığ kadar, ilerleme ve akılc1lık noktasında pozitivist inancı da tartıştı. Ona göre, Batı'nın üstünlüğü medeniyet sisteminin egemenliğinden kaynaklanan ferdî ve içtimaî bir manevi hastalık karşısında önemini yitirmekteydi. Kısakürek'in 1939'da Avrupa medeniyeti hakkındaki olumsuz değerlendirmesinden söz edecek olursak bu tavrın çoğu Avrupalı aydınınkinden pek de farklı olmadığını ifade etmeliyiz. Örneğin, Theodore Adorno 1942'de felaketin farkına varırken Kısakürek'le aynı fikirde olacaktır. ${ }^{17}$

1626 Mayıs 1904'te İstanbul'da doğan Kısakürek, mahalli bir okul (mahalle mektebi), Fransız ve Amerikan kolejleri ve Mekteb-i Fünun-u Bahriye-i Şahane (Deniz Kuvvetleri Okulu) dâhil olmak üzere çeşitli okullara devam etti. İstanbul Darülfünun'da Felsefe Fakültesi'ne kaydolduktan sonra Milli Eğitim Bakanlığı'nın verdiği bir bursla Sorbon Üniversitesi'nde Felsefe eğitimi almak üzere Fransa'ya gönderildi. Pariste'ki bohem hayatı ve oradaki tecrübeleriyle ortaya çıkan ruhî bir bunalım sebebiyle Kısakürek eğitimini tamamlayamadı ve bakanlık tarafından geri çağrıldı. Türkiye'ye döndükten sonra çeşitli bankalarda çalıştı. Kısakürek'in Şeyh Arvasi ile 1934'te tanışması hayatının dönüm noktasını teşkil etmiştir. Karmaşık ve genel şekliyle İslamcı düşüncelerini 1936 'da $A \breve{g} a c ̧$ adlı dergisinde yayımlamaya başladı. Daha sonra Kısakürek, İslamcı siyasi fikirlerini ve Türk tarihini Kemalist düșünce karșıtı bir okuma olarak oluşturduğu dergisi Büyük Doğu'da 1943'te yayımlamaya başladı. 1944'den 1983 'te ölümüne kadar çeşitli mahkeme tecrübeleri ve hapis dönemleri geçirdi. Kısakürek 1950'lerde Adnan Menderes'ten 1960'larda Süleyman Demirel'e, 1970'lerde Necmettin Erbakan'a ve Alparslan Türkeş'e kadar çeşitli muhafazakâr sağ kanat partilerine, Büyük Doğu ideolojisini uygulamaya koymak üzere siyasi liderleri ikna etmek üzere, siyasi destek verdi. 1983 'te ölümüne kadar Türkiye'nin farklı bölgelerinde konferanslar vermeye ve bazı kesintiler olsa da Büyük Doğu dergisini ve kitaplarını yayımlamaya devam etti. Bkz. Anahatlarıyla İlk Necip Fazıl Kısakürek Biyografisi, İstanbul, Büyük Doğu, 2000, s. 2-3. K1sakürek hakkında iyi bir monografi için bkz.: M. Orhan Okay, Necip Fazıl Kısakürek, İstanbul, Şule, 1998.

17 Max Horkheimer - Theodor Adorno, Dialectic of Enlightenment, Standford University Press, 1944, 2007. İlginç bir şekilde ne Kısakürek ne de Topçu Batı medeniyetinin düşüşüne bir 
Kısakürek'in Batı'daki buhranı fark edişi Türkiye'de çağdaşlaşma/Batılılaşmanın çok hızlı adımlarla ilerlediği bir zaman dilimine denk gelmektedir. İslamcı aydınlar, Batı'yla ilgili Türkiye'de hâkim olan çağdaşlaşma çabalarının varılacak son nokta ve mükemmel bir ideal olarak sunulduğu resmi Kemalist söylem ile Batılı aydınların buhran anlayışı arasında önemli bir ayrılık görmekteydiler. Türkiye'deki Kemalist aydın zümre 1930'lar boyunca Avrupa'daki fikrî ve ahlakî buhranı görmezden gelmek zorunda kaldılar, çünkü kendi ülkelerindeki çağdaşlaşma projesi ve siyasi meşruiyeti çağdaş Batı modelinin üstünlüğüne ve evrenselliğine dayanmaktaydı. Bu nedenle Türkiye'deki Kemalist aydın zümreyi eleştiren Kısakürek gibi İslamcılar “medeniyet dönüşümü”nün Cumhuriyet sürecinde yoğun bir Avrupa karşıtlığını sürdürdüler. Avrupalı olmadıklarını söylemekten gurur duyuşlarını ifade etmek için "kendi" yollarını arayan Avrupa-dışı milletlerin zamanının geldiğini tartışmaktaydılar. Kısakürek, Avrupa modelinin irade, dinamizm, ahlâk, nizâm, gençlik ve huzuru temsil etmekten çok uzakta, onu takip edenlerin üzerine karışıklık ve hileyi davet ettiğini, şüphe ve uyuşukluğu teşvik ettiğini ve rahatsızlık ve kasveti miras bıraktığını ifade etmekteydi. ${ }^{18} \mathrm{Bu}$ Avrupa eleştirisi ayrıca, seküler Cumhuriyet aydınlarının meşruiyetine de içten içe bir meydan okumaydı.

\section{Kısakürek'in Doğu'sunun Batı ile Karşılaşması}

Kısakürek'e göre bir Yunan-Latin yapısı olarak Batı medeniyeti Rönesans'1 üreten üç yapıcı unsurla şekil almıştır: Yunan aklı, Roma düzeni ve Hıristiyan ahlâk1 [ve hassasiyeti]. ${ }^{19}$ Modern bilim sayesinde Batı'nın tabiata hakim oluşu on dokuzuncu yüzyıldaki teknolojik gelişmelerle zirveye ulaşmıştır. Yirminci yüzyılda Batı'nın akıl ve ruhu dengelemedeki başarısızlığı ruhî, siyasî, içtimaî ve iktisadî sahada patlak verdi. ${ }^{20}$ Kısakürek Batı kültürel kaynaklarının ve kendi dini anlayışlarının üçlemeci anlayışını Batı ile muvahhit Doğu arasındaki temel farkl11ık olarak tanımlamaktaydı. ${ }^{21}$ Coğrafi sınırlar noktasında Amerika, Batı'yı kuran

işaret olarak afetten söz etmektedir. Roxane Euben, Enemy in the Mirror adlı eserinde, Misırlı İslamcı Seyyid Kutub ile Alman Sosyolog Theodore Adorno tarafindan paylaşılan Avrupa çağdaşlığını bütün olarak lanetleyiş noktasındaki benzerlikten bahsetmiştir. Bkz.: Roxane Euben, Enemy in the Mirror, Princeton University Press, 1999.

18 Necip Fazıl Kısakürek, “Avrupalı Olmamak Şerefi”, 28 Eylül 1939, Çerçeve 1, İstanbul, Büyük Doğu, 1998, 3. bsk., s. 171. Kısakürek'in Türkiye için alternatif tarih yazıcılığı için bakınız: Fahrettin Altun, "Alternatif Tarih Yazmak: Necip Fazıl Kısakürek'in Hafiza Siyaseti," Toplum ve Bilim, 123, 2012, s. 170-203.

19 Necip Fazıl Kısakürek, "Batının Kendisine”, Büyük Doğu 1. yı1, 1/4, 23 Kasım 1945, s. 2; Batı Tefekkürü ve İslam Tasavvufu, İstanbul, Büyük Doğu, 1984, 2. bsk., s. 18.

20 Necip Fazıl K1sakürek, "Kendi İçinde Batı”, Büyük Doğu n. 6, 22 Ekim 1943, s. 2 ve Büyük Doğu, n. 69, 25 Temmuz 1952, s. 4.

21 Necip Fazıl Kısakürek, "Batının Kendisine Bakışı", Büyük Doğu 12. periyot, n. 16, 5 Ocak 1966, s. 2, 5 . 
değerleri sı̆̆ algılayışıyla kitle kültürü alanı olarak görülürken Batı, Avrupa'yla sınırlandırılmıştır. ${ }^{22}$ Kısakürek Batı medeniyetinin buhranının işareti olarak iki dünya savaşını gördü ve Batılı insanın yeni bir dünya düzenine olan acil ihtiyacın1 vurgulad1. Kısakürek'e göre, Komünizm, Faşizm ve Nazizm derin kökleri olan bu buhrana uygulanabilir bir çözüm sunmada başarısızdılar. Onun için, II. Dünya Savaşı sonrası Soğuk Savaş mücadelesi, "iki karşı rejim bloku" şeklinde, Bat1daki buhranı ortadan kaldırmayacak aksine derinleştirecekti, çünkü bu buhran düzen, inanç ve ahlâk yoksunluğundan kaynaklanmaktayd $1 .{ }^{23}$ Kısakürek ayrıca Soğuk Savaş'ın süper güçleri Amerika ve Sovyetler Birliği'ni kültürlerinde Batı medeniyetinin hastalıklarının temsilcileri olarak değerlendirmekteydi. Sovyetler Birliği resmî ideolojide maddeci fakat hayat ve iş tarzında mistik iken Amerika inanışta anti-materyalist fakat yaşam şeklinde maddeciydi. ${ }^{24}$

Kısakürek Batının tabiata hâkimiyetini ve pozitif bilimlerdeki ilerlemesini özellikle Doğu ile olan ilişkisinde belirgin ve en önemli özellik olarak sıklıkla ifade etmekteydi. İnanç adına sürdürülen saçmalıkların artmasına sebep olacak "Doğu'da Rönesans" şeklindeki gelecek idealine önem veriyordu. ${ }^{25}$ Kisakürek'e göre Batı'nın aslını şekillendiren Rönesans kavramı aslında Kur'an'da Müslümanlara emredilen bir görevdi. Rönesans"ın özünde İslam'a ait olan "eşyayı ve olayları (maddeyi) fethetme ve hâkimiyeti altına alma" şeklindeki esas felsefesi hakkında fikir yürüttü. ${ }^{26}$ İdeal olarak düşünüldüğünde Müslümanlar kısmen Batı'dan ilham alınan yeni bir akılcı Rönesans'ın ilkeleriyle kendi ahlâki değerlerini bir araya getirmek zorundaydılar. Kısakürek' in tartıştığı Batı'nın akılcılığı ile Müslüman maneviyatının gelecekteki sentezi Hindu aydın Rabindranath Tagore'un Hindistan ve Asya konusundaki fikir yürütmesine benzemekteydi. ${ }^{27}$ İlginç bir şekilde, Kısakürek medeniyet sentezi fikrinin bir sonucu olarak Batı'dan Müslüman toplumların kültürel fikir alış verişinde bulunmalarını meşru görmekteydi.

Kısakürek'in zihninde oluşan Batı'nın olumlu tarafı dinamikliği ve tabiat üzerinde insan hâkimiyetini mümkün kılma başarısı, olumsuz tarafı ise inanç pahasına maddeye ve kemiyete bağlı olmasıydı. ${ }^{28}$ Doğu/İslam dünyasının ihtiyaç

22 Necip Fazıl Kısakürek, "Kendi İçinde Batı" s. 2.

23 Necip Fazıl Kısakürek, "Batının Buhranı”, Büyük Doğu 1. yıl, 1/19, 19 Kasım 1943, s. 2; Büyük Doğu, n. 11, 19 Haziran 1959, s. 2.

24 Necip Fazıl Kısakürek, "İki Ejderha”, Büyük Doğu 24. y1l, 13. periyot, n. 18, 15 Kasım 1967, s. 5; ayrıca Başmakalelerim 3, İstanbul, Büyük Doğu, 1995, s. 250-252. Ayrıca bkz.: "Batının Ucuzculuğu”, Büyük Doğu n. 4, 28 Mayıs 1954, s. 2.

25 Necip Fazıl Kısakürek, Konuşmalar, İstanbul, Büyük Doğu, 1994, 2. bsk., s. 106; Dünya Bir İnkllâp Bekliyor, İstanbul, Büyük Doğu, 1993, 3. bsk., s. 30.

26 Necip Fazıl Kısakürek, Sahte Kahramanlar, İstanbul, Büyük Doğu, 1987, 4. bsk., s. 148-149; Yeniçeri, İstanbul, Büyük Doğu, 1977, 2. bsk., s. 12.

27 Stephen N. Hay, Asian Ideas of East and West: Tagore and His Critics in Japan, China, and India, Harvard University Press, 1970.

28 Necip Fazıl Kısakürek, Batı Tefekkürü ve İslam Tasavvufu, s. 22. 
duyduğu Rönesans, "kendi bâtıl dininden (Hıristiyanlık) kurtulup, aklı tekrar ele geçirmek için" yapan Batı'dakinden (bilinenin aksine de olsa) farklıydı. İslami yenilik Avrupa'nın yaptığ 1 gibi inancın karşısında aklı yarıştırmak zorunda değildi. Müslümanlar dini inançlarına meydan okumadan ve hatta İslam'ın "küfür ve hurafeden sıyrılıp onu bütün asliyetiyle tekrar bulmak için" inançlarının "saf" aslını canlandırarak kendi Rönesans'larına sahip olabilirlerdi. ${ }^{29}$

"Doğu”daki hâkim Batılılaşma hareketlerine gelince, K1sakürek Müslüman modernistlerin Batı odaklı girişimlerinin Batı'nın sadece olumlu, teknolojik sürecini hesaba kattıklarına inanıyordu. Bu tek taraflılık Batılılaşmaya maruz kalan ülkelerin manevi özlerini reddetmeleriyle sonuçland1 ${ }^{30}$ Ayrıca bu redde hem Batıcılar hem de modernist Müslüman aydınlarca ahlâksız, barbar ve tarihe karışmış olduğu düşünülen Doğu medeniyetinin mirasının reddi de eşlik etti. Kısakürek’e göre, Yunan ve Roma zamanından Rönesans'a ve günümüze kadar Bat, Doğu'yu "[v]âkıaların hendesî ihtar ve icabından anlamayan... suçlu/barbar insan kadrosu" olarak kavramsallaştırdı. ${ }^{31}$ Doğulu insan, bir yandan içe kapanık, biçare, enayi ve "karanlık ve dolaşık hayaller" peşinde koşan, ve öte yandan da ruhî harikalar yaratandır. ${ }^{32}$ Kısakürek Batı'nın oryantalist "Şarklı" söylemini eleştirmektedir. Eğitimli Avrupalıların bile hala şuna inandığını belirtmektedir: "Şark, ... fert ve hürriyet değerini bilmeyen, sultanlar ve despotlara baş eğen, ... koca bir ölçüsüzlük ve şuursuzluk âlemidir."’33

Fakat, Avrupa Oryantalizmini eleştirmesine rağmen Kısakürek'in Türkiye'nin çağdaşlaşmasına bakışı Avrupa-merkezcilikten azade değildir. Kısakürek'e göre Şarklı'nın "ne ilmi vardır, ne tenkidi... Dindar olabilir, fakat sebep ve netice arayıcısı ve fikirci olamaz." Sebeple bağlantı kurmaksızın Kısakürek Doğuluların eşya ve olaylar üzerindeki hâkimiyetini yitirdiğini ifade eder. Dahas1, tabii dünyanın özünü anlamada yetersiz olduğundan Doğulu, Batı'nın makine ve madde keşifleri âlemini benimsemede başarılı olamazdı. Sonraki ifadeler bunu netleştirir, Kısakürek Doğu'da çağdaşlaşma hareketlerinin Batı'yı kavramaktan uzak olduğu, daima satıhta ve aciz kalacağı şeklindeki Oryantalist gözlemi paylaşmıştır. ${ }^{34}$ Öte yandan, Batı düşüncesine sayısız eleştiriler sunsa da Kısakürek' in yükseliş ve düşüş hikâyesine sarılması ve Doğu'nun reddettiği tembelliği anlattı$\breve{g} 1$ oryantalist tartışması onun ne kadar da Avrupalı olmayan toplumlar hakkında Avrupa hikâyelerine dayandığını göstermektedir.

29 Necip Fazıl Kısakürek, Batı Tefekkürü ve İslam Tasavvufu, s. 215.

30 Necip Fazıl Kısakürek, "Batının İki Yüzü”, Büyük Doğu 24. yıl, 13. periyot, n. 19, 22 Ekim 1967, s. 5.

31 Necip Fazıl Kısakürek, “Batı'nın Doğu’ya Bakışı”, Büyük Doğu 2. yı1, n. 15, 30 Mayıs 1952, s. 4.

32 Necip Fazıl Kısakürek, “Batı'nın Doğu’ya Bakışı”, s. 4.

33 Necip Fazıl Kısakürek, "Batı'nın Doğu'ya Bakışı”, s. 4.

34 Necip Fazıl Kısakürek, “Batı'nın Doğu’ya Bakışı”, s. 4. 
Yine de Kısakürek'e göre "Her şey Doğu' dan geldi” - O, insanlığın maddenin ötesine geçerek yüce mucizeyi bulduğu yerdi (tüm tek tanrılı dinler ve peygamberleri dâhil): "Ruh, mucize, masal, büyü, şiir... bütün hak ve bâtıl kutuplariyle Doğudadır." ${ }^{35}$ Doğu'nun gerilemesinin sebebi Batı'nın Rönesans'1 değil, Doğu'nun tembelliğe düşmesidir. Doğu'nun gerilemesinin ilk işareti metafizik; yani din alanında ortaya çıktı. Din (İslam) karşısındaki gerici tavır Batılılaşma sürecinde (Osmanlı Tanzimat dönemi ya da Cumhuriyet dönemi bürokratları gibi) "Doğuyu kaybetmiş, Batıyı da bulamamış" "sahte kahramanlar"ın belirmesiyle başarılı oldu. ${ }^{36}$ Ruhî alandaki ihtişamının aksine, tabiat üzerindeki akıl hâkimiyeti, Doğu'nun Batı'nın maddi gelişimi karşısında sahip olduğu aşağılık duygusuyla mücadele eden ve galibiyetini sağlayan Aşil'inin topuğuydu. Aşağıllık kuruntusu [Küçüklük ukdesi] Haçlı Seferleri'nden daha zararlıydı çünkü genel olarak Doğu dünyasında, özel olarak da İslam âleminde taklitçi inkılâpçılar peydahladı. ${ }^{37}$ Doğunun esas insan ırkını [mayasını] Çin, Hint, Fars, Arap ve Türkler oluşturmaktaydı. Fakat Doğu, ihtişamına İslam'la [Büyük Tecelli] kavuştu ve böylece Müslümanlar hem Doğu'da hem Batı'da kendi medeniyetlerini temsil görevlerini belirgin hâle getirdiler. Arapların düşüşünden sonra Türkler özellikle Doğu medeniyetinin unsurlarını Batı medeniyetinin coğrafi merkezi olan Avrupa'ya ulaştıran Osmanlı'nın Avrupa'ya doğru genişlediği dönemde Doğu'nun tek örneği [baş örnekliği] hâline gelmişti. ${ }^{38}$ Kısakürek'in Osmanlı'nın Avrupa'ya açılmasını Doğu-Batı medeniyet sentezi için bir firsat olarak değerlendirmesi çelişkili görünse de nihayetinde o, Büyük Doğu'nun yeni Asyacılık'ının, Batı'nın maddi ve pozitif bilimlerdeki başarılarıyla Doğu'nun ruhî ve dinî başarılarını bir terkip haline getirilebileceğine inanıyordu. ${ }^{39}$

\section{Batı Siyasi İdeolojileri ve Kemalizm}

Kısakürek'in Batı ile ilgili fikirleri Türkiye'deki aktif siyasi tutumuna bağlı olduğu için Kısakürek'in yazılarındaki Batı portresinin tam olarak anlaşılması onun siyasi görüşünün dikkatle incelenmesini gerektirmektedir. Kısakürek'in görüşüne göre, Komünizm, Kapitalizm ve Faşizm gibi çağdaş siyasi ideolojiler İslam'la doruğa ulaşan tek tanrılı dinlerin geçmişte başardığı, günümüzde ve gelecekte de başarabileceği şekilde insanların içtimaî ve ferdî hayatları üzerinde bir

35 Necip Fazıl Kısakürek, "Doğuya İnanalım”, Büyük Doğu 9. y1l, n. 41, 27 Haziran 1952, s. 4; "Doğunun Kendisine Bakışı", Büyük Doğu 9. yı1, n. 36, 20 Haziran 1952, s. 4.

36 Necip Fazıl Kısakürek, "Doğunun Ucuzculuğu”, Büyük Doğu. n. 3, 21 Mayıs 1954, s. 2.

37 Necip Fazıl Kısakürek, "Doğuya İnanalım", 4; "Doğunun Kendisine Bakışı", s. 4.

38 Necip Fazıl Kısakürek, "Doğunun Mizanı”, Büyük Doğu 1. y1l, 1/5, 15 Ekim 1943, s. 2; "Kendi İçinde Doğu”, Büyük Doğu 9. yıl, n. 62, 18 Temmuz 1952, s. 4; Büyük Doğu n. 11, 15 Mayıs 1959, s. 2.

39 Necip Fazıl Kısakürek, “Asyacılık-Avrupacıl1k”, Büyük Doğu 1. y11, 2/29, 17 May1s 1946, s. 2; ayrıca bkz.: Konuşmalar, s. 89-90; Batı Tefekkürü ve İslam Tasavvufu, s. 100. 
başarı elde edemezler. Kısakürek'in ideoloji tanımı, "mücerret fikrin maddeye aksi" olarak "ferdin ve cemiyetin inşasındaki bütün esasları veren fikirler manzumesi" şeklindedir. ${ }^{40}$ Ayrıca ilk mükemmel ideolojilerin de dinler olduğunu ifade etmiştir, çünkü insanoğlunun ilk fikri Allah fikridir ve böyle de kalmıştır. Son ve mükemmel tek tanrılı din olan İslam'ın ferdi ve cemiyeti çepçevre kuşatan kat'i bir din olduğunu ifade etmiştir. ${ }^{41}$

Kısakürek çağdaş ideolojiler arasında Komünizm'in Batı toplumunun zayıflığına [binbir tezat ve çürüklüğe] dikkat çektiğine fakat aynı zamanda kurtuluş adına bütün ruhî kıymet ölçülerini yıkarak Batı münevverinin intiharını temsil etiğgine inanmıştır. ${ }^{42}$ Aksiyon değil; dine, idealizme, metafizik düşünceye ve ferdî mülkiyete reaksiyon olması yönüyle bu ideoloji, ayrıca önemli bir unsurunu yitirmiştir. Kısakürek'e göre Komünizm'in en kabul edilemez tarafı [en büyük abes] bütün ruhçu kıymetleri, dini, milliyetçiliği, ahlâkçılığı ve aileyi reddetmesidir. Öte yandan Komünizm'in maddeci ahlâkına rağmen, Kısakürek 1917'deki Rus ihtilalcilerinin fedakârlığını da takdir ederek hatırlamaktadır. ${ }^{43}$

Kısakürek'in incelemesine göre İslâm dünyası iki sebeple Soğuk Savaş mücadelesinde Komünizm karşısında Batı demokrasileri tarafında yer almak zorundaydı. Birincisi, Ortadoğu Müslümanlarına hâkim olan ve zulmeden bir Sovyet Rusya önderliğinde Komünizm'in tasfiye edilmesi, Müslüman dünyasının Batı emperyalizminden intikam almasını sağlayabilirdi. İkincisi, İslam'ın ve Türklerin tarihi düşmanı Rus İmparatorluğu yeni ideolojik silahı Komünizm'le birlikte ortadan kaldırılırdı, bu, İslam dünyası ve Türkiye'nin canlanmasının önünü açacaktı. ${ }^{44} \mathrm{Bu}$ inceleme Kısakürek'in son Osmanlı dönemi sömürgecilik karşıtı Pan-İslamist tarihi bilincini nasıl sürdürdügünü göstermektedir. Yine de, Soğuk Savaş'a, milliyetçi güçleri sömürgelikten kurtulmada desteklemek üzere baskıcı Batı güçleriyle bir mücadele olarak baktı. Aynı zamanda, Kısakürek yeni bağımsızlık hareketlerine pek ilgi duymaksızın Soğuk Savaş mücadelesinde Sovyet Rusya karşısında kapitalist bloka öncülük eden Amerika'yı desteklemesi için Türkiye'ye 1srar ediyordu.

Bir ideoloji olarak Komünizm eleştirisinin yanısıra Kısakürek, 1960’larda Türk gençliği üzerinde Komünizm'in etkisinin büyümesi karşısında direnç göstermesi için takipçilerini teşvik etmekteydi. Komünizm'in yakın tehdidi o döne-

40 Necip Fazıl Kisakürek, Sahte Kahramanlar, s. 247, 258.

41 Necip Faz1l Kisakürek, Sahte Kahramanlar, s. 250, 254.

42 Necip Fazıl Kısakürek, "Batının Buhranı”, Büyük Doğu 1. yıl, 1/19, 19 Kasım 1943, s. 2; Ihtilal, İstanbul, Büyük Doğu, 1997, 6. bsk., s. 281.

43 Necip Fazıl Kısakürek, "Materyalizma ve Komünizma”, 1949, Hitabeler, İstanbul, Büyük Doğu, 1985, 2. bsk., s. 11, 17, 21, 31; Dünya Bir Inkılâp Bekliyor, s. 130-131.

44 Necip Fazıl Kısakürek, "Tarihi Vade”, Büyük Doğu 9. yı1, n. 103, 28 Ağustos 1952, s. 1; ayrıca, Başmakalelerim 1, İstanbul, Büyük Doğu, 2013, s. 207-209. 
min Türk săg kanadı siyasi partilerinin dikkatini çeken bir meseleydi. Kısakürek ideolojik coşkunun Komünizm'e kanalize olmasının, Kemalist Cumhuriyetçi Halk Partisi’nin benimsediği İslam karşıtı politikalarının bir sonucu olduğunu düşünüyordu. Özellikle Köy Enstitüleri’nin din karşıtı eğitimi ve İslami değerlerin yayılmasından çekinmelerine de değindi. 1940'lardan 70'lere kadar, Kısakürek Kemalizm'in sekülerleşme politikaları ile Türkiye'de Komünizm'in yayılmas1 arasında bağlantılar kurdu. ${ }^{45}$ Ona göre Kemalizm genç Türkiye'ye gerçek bir ideoloji sunmakta başarısız olduğunda İslam ve Komünizm alternatifler olarak ortaya çıktı. Bu yüzden İslam, yaklaşan Komünist ihtilâlin ve onun zihinlerini ve enerjilerini verecekleri ve mevcut düzene karşı savunacakları bir ideolojiyi bekleyen Türk gençliği üzerindeki zararlı ideolojik etkilerinin önleyicisi olarak görünmekteydi ${ }^{46}$ Ona göre Faşizm ve Nazizm, Liberalizm ve Komünizm'e birer tepkiydiler ve ayrıca Batı'nın, ruhu arama teşebbüsleriydiler. ${ }^{47}$

Kısakürek'in Batı algısıyla ilgili olarak tartışılması gereken son önemli unsur Yahudi meselesidir. Onun Yahudilerle ilgili fikirleri 1rkçı ve özcü özellikler barındırmaktadır - Onları Batı medeniyetinin ahlâkını bozanlar olarak değerlendirmektedir. Yahudi karşıtı düşüncelerinin çoğunu Batı"dan alan Kısakürek Yahudileri Marksizm ve Kapitalizm'in mucitleri olarak tanımlamakta ve Müslümanlar arasındaki ilk fitnelerden, Osmanlı İmparatorluğu'nun gerilemesinden, Türkiye'nin çağdaşlaşma hareketi taklidinden ve Türk milli zaferlerinden hemen sonra 1924'te halifeliğin kaldırılmasından sorumlu tutmaktadır. ${ }^{48}$ Osmanlı Yahudilerinin Osmanlı İmparatorluğu'na sadık kaldıkları ve örneğin Hıristiyan milliyetçiliğiyle ilgili olarak genellikle Osmanlı Müslümanları tarafında yer aldıkları gerçeği düşünüldüğünde, Kısakürek'in Yahudilerin Osmanlı İmparatorluğu'nu zayıflattı̆̆ komplosu açıklamasının tarihi geçerliliği yoktur. Dahası, son Osman11 dönemi İslamcıları Yahudi karşıtı görüş beyan etmezler. Aksine, bu dönemin çoğu İslamcısı ezilen diğer Avrupalı Hıristiyanlar kadar Müslüman ve Yahudilerin kaderlerinde benzerlikler görmüşlerdir. Bu arka plan göz önüne alındığında, Kısakürek'in Yahudilerle ilgili yeni İslamcı söylemi Cumhuriyet dönemi entelektüel hayatına Avrupa'nın Yahudi karşıtı literatürünün etkisi kadar çokuluslu Osmanlı geçmişinden milliyetçi bir kopuşu da göstermektedir.

45 Necip Fazıl Kısakürek, “Komünizma”, Büyük Doğu 14. periyot, n. 3 ( Temmuz 1969), s. 3; "Moskof", Büyük Doğu, 28. y1l, 15. periyot, n. 10, 10 Mart 1971, s. 3; Çepçevre Sosyalizm, Komünizm ve İnsanlık, İstanbul, Büyük Doğu, 1985, 2. bsk., s. 109-110; "Materyalizma ve Komünizma”, s. 32-51.

46 Necip Fazıl Kısakürek, “Komünizma Geliyor”, 1962, Hitabeler, s. 47; İhtilal, s. 352.

47 Necip Fazıl Kısakürek, "Faşizma", 23 Mart 1939, Çerçeve 1, s. 70-71; Sahte Kahramanlar, s. 292-293; Ihtilal, s. 317.

48 Necip Fazıl Kısakürek, Sahte Kahramanlar, s. 45; Doğru Yolun Sapık Kolları, İstanbul, Büyük Doğu, 1996, 7. bsk., s. 16, 73; "Buhranımızın Kundakçısı Yahudi”, 27 Haziran 1980, Rapor 10/13, İstanbul, Büyük Doğu, 1993, 2. bsk., s. 13. 


\section{Batı, İslami Bir Rönesans/Çağdaşlık Hareketi Sağlayabilir Mi? Nuret- tin Topçu}

Nurettin Topçu, belki de yeni bir Cumhuriyet İslamcılık'ının fikirsel şekillendiricisi olarak Necip Fazıl Kıskaürek’ten sonra ikinci aydındı. Kısakürek tıpkı İslamcılar gibi seküler Kemalistlerin de şiirlerine hayranlık duyduğu ve beğeni beslediği efsanevî bir şair olarak tanınmaktaydı. Kısakürek ayrıca Türkiye'deki dindar milliyetçi yeni nesil gençlik tarafından sıkı takip edilen ünlü bir tartışmacıydı. Kısakürek'in aksine, Topçu, eğitimli İslamcılar üzerinde odaklanan etkisiyle daha ilmiydi. Kısakürek ve Topçu Türkiye'nin yeni İslamcı gruplarının benzer kesimleri tarafindan okunan ve hayranlık duyulan tamamlayıcı bir role sahiptiler.

Topçu, felsefe eğitimi almak üzere Paris Sorbonne Üniversitesi’ne gönderilen ilk Türk öğrenci grubu içerisindeydi. 1934'te "Conformisme et Révolte" adl1 doktora tezini tamamladı. Türkiye'ye dönüşünün ardından Nurettin Topçu İslamc1lık'la Türkçülük'ü birleştiren, 1950'lerin ilk yıllarından 1960'lar döneminin en ilginç ideolojik terkiplerinden birini sundu. ${ }^{49}$ Topçu, Necip Fazıl Kısakürek gibi Türkiye bağlamında aynı büyük meselenin "Doğu'nun Batı'yı tanıması" olarak adlandırılan sorunu ile ilgilendi, fakat çözüm olarak farklı bir ideolojik terkip sundu. Batı medeniyeti ve Hıristiyanlık ile ilgili değerlendirmeleri de hemen hemen Kısakürek'inden tamamen farklıydı. Dahası, Kısakürek Doğu ve Batı arasında İslam ruhunu birleştirici olarak belirtirken Nurettin Topçu Anadolu İslam sosyalizmi ve milliyetçiliği fikirleri çerçevesinde çalıştı ve bu terkibi Anadolu yarımadasında baskın Müslüman tecrübe olarak İslam'ın eşitlikçi fikirleriyle bütünleştirdi. Neticede, Topçu'nun ahlakçı/ruhçu sosyalizmi eşitlik, İslamî metafizik düşünce ve ahlâka yapılan özel vurgu ile milli “Rönesans"a bir önem atfetti.

Topçu'nun [Anadolu] İslâm sosyalizmi devletçilik, otoriter rejim ve işbirlikçilikten etkilenmekteydi. ${ }^{50}$ Avrupa'nın buhran dolu bir taklidinden ziyade Avrupalı olmayan milletlerin "kendi yollarını" aramaları gerektiğini savunan Necip Fazıl'ınkinden farklı olmaksızın, Topçu'nun ideolojik formülasyonu Kapitalizm ve Komünizm karşısında üçüncü bir yol sunmaktayd $1 .{ }^{51}$ En önemlisi dinin (İs-

49 1909'da İstanbul'da doğan Topçu, Erzurum'da Topçuzadeler olarak bilinen bir aileden gelmektedir. Babası Ahmet Efendi tüccardı ve annesi Fatma Hanım'dır. Topçu Bezmialem Valide Sultan, Büyük Reşit Paşa Numune, Vefa ve İstanbul Lisesi okullarına devam etti. Hallac-1 Mansur'un tasavvufundan ilhamla İslam'da hareketin bulunduğu yorumuna dayanan bir hareket felsefesi geliştirdi. Türkiye'ye döndükten sonra öğretmen oldu ve Galatasaray, İstanbul Lisesi ve Robert Koleji dâhil çeşitli liselerde 1934'ten 1974'e kadar öğrencilerine eğitim vermeye devam etti. Hareket adlı dergisini 1939 'da yayımlamaya başladı ve 1975 'te ölümüne kadar çeşitli kesintiler olsa da yayınına devam etti.

50 Nurettin Topçu, "Eşitlik Davası”, Komünizme Karşı Mücadele 22, 15 Haziran 1951, Ahlak Nizamı, İstanbul, Dergâh, 1997, 3. bsk., s. 32-36; Ahlak Nizamı, s. 25, 108-112, 174.

51 Nurettin Topçu, Yarınki Türkiye, İstanbul, Dergâh, 1997, 4. bsk., s. 63. 
lam) milli yorumunun korunması, Türkiye tarihi ve Anadolu toprakları bağlamında, Topçu'ya göre, muhafazakarlık, milliyetçilik ve İslam arasında bir ortak yaşam ilişkisi gerektirmekteydi. ${ }^{52}$ Batı medeniyetinin siyasi, içtimaî, ruhî ve iktisadî buhranlarına dikkat çeken Kısakürek'e paralel olarak Topçu da Kemalist milliyetçiliğin seküler ve modernist tabiatından rahatsızlık duyuyordu. Çözüm olarak, Avrupa topraklarında değil Anadolu vatanına yerleşmiş vaziyette olduğunu iddia ettiği mistik ve içtimaî fikirler çerçevesinde bir “Türk-İ́slam sentezi” öngördü. Bu yeni İslami milliyetçi şekil sadece Kemalist milliyetçilik ve Turancıllk'a değil aynı zamanda Mehmet Akif Ersoy ve diğerlerinin yazılarında görüldüğü gibi İkinci Meşrutiyet döneminin Pan-İslamizm'ine de bir alternatif teşkil etti. ${ }^{53} \mathrm{Bu}$ manada Topçu net olarak, yeni bir milliyetçilik ve İslam terkibi formülüne dayandırdığı inanç olarak homojen bir Anadolu'ya odaklanan, Lozan Antlaşmass ${ }^{54}$ sonrası İslamcı bir kimliktir.

Topçu'nun fikirleri İslamcıllk' $\mathrm{n}^{55}$ milliyetçi terimlerle açıklanan ve İslam medeniyetinin bir Türk-İslam medeniyeti şeklinde tanımlanmasına dayanan bir türünü yansıtmıştır. ${ }^{56}$ Fakat milliyetçi dile rağmen Topçu, İslam'1 Türk millî kimliğinin karakteristik unsuru olarak kabul ettiği için ideolojisinin düzenli yapısının dine bağlı olduğunu belirtmek önem arz etmektedir. Kısacas1, Topçu'nun milliyetçi formülünde Türk milliyetçiliğinin maddesi olarak Anadolu vatanını, ruhu olarak da İslam'1 kabul edişi merkezi rol oynamaktayd..$^{57}$ İslami Doğu'daki ayrışmaları düzenlemeyi İslami bir Rönesans olarak adlandıran Necip Fazıl'ın fikir-

52 Bkz.: Nurettin Topçu, Mehmet Akif, İstanbul, Dergâh, 1998, 2.bsk., s. 42-45.

53 Nurettin Topçu, "Benliğimiz", Hareket 1/4 (Mayıs 1939), Yarınki Türkiye, s. 111, 117-8; Ahlak Nizamı, s. 143-149 ve Süleyman Seyfi Ögün, Türkiye'de Cemaatçi Milliyetçilik ve Nurettin Topçu, İstanbul, Dergâh, 1992, s. 24, 44, 83-93. Topçu'ya göre Gökalp'in Turancıllk’1 Türk ulusu üzerindeki Arap etkilerinden sıyrılmak için araştırılmasıyla, İslam milliyetten ayrıldı ve kültür ve inançta buhranların oluşmasından sorumlu hale geldi. Bkz.: Yarınki Türkiye, s. 36.

54 Lozan Antlaşması 1923'te imzalanan ve Türkiye Cumhuriyeti'nin o dönemdeki sınırları üzerindeki bütüncül hâkimiyetini tanıyan barış anlaşmasıdır. Aynı zamanda Osmanlı İmparatorluğu'nun uluslararası meşru mevcudiyetini sona erdirmiştir. Bu antlaşmanın bir bölümü Yunan-Türk nüfus mübadelesini şart koşarak inanç olarak homojen bir toplum oluşturmuştur.

55 İslamcı fikirleri Mehmet Akif Ersoy, Sait Halim Paşa, Afgani and Babanzade Ahmet Naim'den etkilenmiştir. Fikri İslamcılık'ından ayrı olarak Topçu gerçekten siyasetçiler ve siyasi partiler elinde İslam'ın siyasileştirilmesini sert bir şekilde eleştirmiştir. Bkz.: "İslamı Sömüren Siyaset", Íslam ve Insan, İstanbul, Dergâh, 1998, s. 106-108.

56 Nurettin Topçu, Yarınki Türkiye, s. 92. Türkiye'de İslam ve milliyetçilik arasındaki uyum hakkında bir çalışma için bkz.: Gökhan Çetinsaya, "Rethinking Nationalism and Islam: Some Preliminary Notes On the Rrots of Turkish-Islamic Synthesis in Modern Turkish Political Thought," The Muslim World LXXXIX/3-4, ( July-October 1999), s. 350-376.

57 Nurettin Topçu, "İçtimai Sinıflar", Hareket 1/2 (Mart 1939) ve 1/3 (Nisan 1939), Yarınki Türkiye, s. 224-5. Topçu Pan-İslamizm'i coğrafya ve iktisadın milletin maddi tarafını teşkil ettiği ve ruhu olan İslam ile maddesi olan Anadolu toprağı arasında bir ayrılık olamayacağı gerçeğini ihmal etmesi sebebiyle eleştirmekteydi. Bkz.: "Bizde Milliyet Hareketleri”, Hareket 1/3 (Nisan 1939), Yarınki Türkiye, s. 134. 
lerine paralel olarak, Topçu ayrıca saf İslam'ın Türk toplumunun özüne şekil vermesi gerektiği fikrini özenle eklemekteydi. Necip Fazıl'dan ayrıldığı nokta erken dönem saf İslam tasavvuruna dönüşü değil bir Anadolu romantizmini uyandırmak için Türk Müslümanların dini anlayışlarını değiştirmenin gerekli olduğunu düşünmesiydi. Bu, Topçu'nun Batı'nın yükselmesinin esas sebepleri olarak 1slahat ve rönesansı görmesi ve Türkiye Müslümanlarının Anadolu'nun İslam yorumunun canlandırılmasıyla bir rönesans yaratabileceklerine olan inancıyla ilgiliydi.

İslamcı söylemin temel argümanının aksine Topçu, şeriat fikrine yeni Türk toplumu tasavvurunda merkezi bir rol vermiyordu. Bu ihmal, katı şeriat takipçilerini İslami dünyada Batı pozitivistleriyle eşdeğer görmesinden kaynaklanıyordu. ${ }^{58}$ Bir diğer aşamada, Sufilik'i pasiflik ve uysallığa sebep olan bir şey olarak küçümseyen on dokuzuncu yüzyıl İslamcı modernistlere katılmıyordu. ${ }^{59}$ Topçu Vahdet-i Vücud inanışıyla beraber entelektüel Sufi birikiminden, hareket ve dinamizmin yeni bir İslami felsefesini oluşturmayı denedi. Topçu'nun önem verdiği entelektüel Sufilik'in iki yönü vardır: birincisi, İslami monizm [bir Allah'a inanmak] fikrini kullanarak bir çeşit Hümanizm ve evrensellik kurmaya çalıştı. İkincisi, Sufilik'i Türk milliyetçi-romantizminin ya da yeni İslam medeniyetinin esası olarak kulland1. ${ }^{60}$

\section{Batı’nın Özcü Olmayan Bir Tarafı: Rönesans ve Romantizm}

Topçu'nun kavramsallaştırmasında "Batı” Yunan, Roma İmparatorluğu, Ortaçağ Avrupası, Rönesans, Romantizm ve son olarak Sanayi Devrimi'nin geleneklerinden meydana gelen bir medeniyet ya da kültür olarak ifade edilmiştir. Topçu'ya göre Batı'nın çağdaşlaşma tecrübesinin sadece son kısmı, diğerleri oldukça övülürken, Avrupa ve insanlık için yıkıcı bir unsur olarak görülmektedir.

Topçu'nun bir medeniyet olarak Batı ile ilgili görüşünün kilit noktası Batı'nın özcü bir imajına ya da agnostik tavrına dayanmamasıdır. Daha doğrusu, o Batı'yı ahlakta bir rönesans başarısı ve "ilim düşüncesi”"nde açılım yapmak için alınacak bir örnek olarak değerlendirmekteydi. Batı'nın skolastik felsefeden kurtularak

58 Nurettin Topçu, "Din Hayatı”, Komünizme Karşı Mücadele, 36, 15 Mayıs 1952, Ahlak Nizamı, s. 82; Íslam ve Insan, s. 21-22. Topçu'nun bakış açısına göre, İslam dünyasının gerilemesinin sebepleri harici olmaktan ziyade dahili olarak algılanıyordu. Haçlı Seferleri ve Moğolların Türk-İslam medeniyeti üzerindeki olumsuz etkilerinden bahsetmesine rağmen Topçu gerilemenin sorumluluğunu skolastik felsefe [iskolastik düşünce] ve sahte din adamlarına yükledi. Bkz.: İslam ve Insan, s. 43, 49-50; Yarınki Türkiye, s. 93.

59 Sufilik'in modern bir eleştirisi için bkz.: Mazheruddin Sıddıqi, Modern Reformist Thought in the Muslim World, Delhi, Adam Publishers and Distributers, 1993, s. 14-23.

60 Nurettin Topçu, Mevlana ve Tasavvuf, İstanbul, Dergâh, 1998, s. 116-121, 129-133; Isyan Ahlakl, İstanbul, Dergâh, 1995, s. 166-168, 173; Kültür ve Medeniyet, İstanbul, Dergâh, 2010, 5. bsk., s. 91 ve İradenin Davası, İstanbul, Dergâh, 1998, s. 71. Sufillik'in hareket duygusunun kaybına sebep olduğu şeklindeki modernist iddiayı reddetti. Bir anlamda Maurice Blondel'in hareket felsefesini İslami terimlerle kullanarak takdim etti. 
özgürlüğe erme çabası imrenilecek ve Türk milleti tarafından uygulanacak bir şeydi. ${ }^{61} \mathrm{Bu}$ manada, Topçu Avrupa'yı ortak insanlık mirasının bir Türk rönesansına ilham olabilecek sahibi olarak gördü. Batı'nın örneklik durumu ilham verici bir kaynak olduğu halde, hakikatte Türkler tarafindan taklit edilemezdi. Aksine, Batı rönesansının çağdaşlaşma karakteri, Türk milli/romantik ve İslami kaynaklarıyla değil bunlardan azade bir Türk rönesansı oluşturma ihtiyacını işaret etmekteydi. Decartes ve Blodel gibi bazı Batılı düşünürler insanlığın tamamı için konuşan ve aynı zamanda Türk rönesansına katkıda bulunacak olan düşünürler olarak takdim edildi. ${ }^{62}$

1930'ların sonlarındaki yazılarında Topçu "rönesans" sözcüğünü çağdaşlık kavramı ile tanımlamış ve antik Yunan, ortaçağ İslam'ı ve en çok da Avrupa' daki gibi insanlık tarihinde çeşitli rönesansların var olduğundan söz etmiş olarak görünmektedir. Bu çoklu rönesanslar fikri S. N. Eisenstadt'1n "çoklu moderniteler" tanımlamasına denk bir yorumlama olabilir. ${ }^{63}$ Ona göre bütün Rönesans hareketleri dış âlemden kendine, kâinatın fizik izahından ruhî değerlerin yaratılışına doğru bir hareket teşkil etmekteydi. Her Rönesans ürünü -ilim, sanat, felsefe ve hukuk- bir cemiyet tarafından geliştirilmiş olsa da insanlığın tamamına aitti. Her Rönesans, karanlıktan bir kurtuluş olarak, yeni bir terkip oluştururken diğer medeniyetlerin tecrübelerini ödünç alırdı. ${ }^{64}$

Topçu'nun Batı'nın yükselişinin kaynakları olarak Rönesans ve Romantizm tanımlaması onu, Batı tarihini insanlık tarihinin bir parçası olarak alan bütün toplumları kapsayan bir evrenselcilik bakışına ulaştırdı. Çağdaş Batı'nın sanayileşmesini eleştirmesi Batı medeniyetine karşı olan bir görüşe sebep olmadı. Topçu, on dokuzuncu ve yirminci yüzyıl sanayiini sert bir şekilde eleştirmesine rağmen aynı Avrupa'nın Rönesans ve Romantizm başarılarını takdir etti. Bu nedenle, Topçu bu noktada ve sadece Avrupa teknolojisini ve sanayisini değil inanç, kültür ve değerlerinin meziyetlerini vurgulaması yönüyle genel İslamcı eğilimden ve Nezip Fazıl'dan da ayrılmıştır. Hatta Batı ahlâkının meziyetlerinden bile söz etmiştir. İslamcı yaşam anlayışının daha önceki biçimleri bazı maddi ve bilimsel gelişmelerde bazı başarılar elde etmiş olsa da genellikle Batı'nın ahlâk olarak düşüklüğü fikrine dayanmaktaydı. Burada Topçu, Batı'nın ayrıca ahlâk ve felsefe noktasındaki üstün oluşunu alışılmadık bir argüman olarak sunmaktadır:

61 Nurettin Topçu, “Garbın İlim Zihniyeti ve Ahlak Görüşü” (1955), Kültür ve Medeniyet, s. 33.

62 Nurettin Topçu, "Ahlak Nizamı," Hareket 2/1 (Mart 1947), Ahlak Nizamı, 17; Kültür ve Medeniyet, s. 33.

63 "Çoklu moderniteler" kavramı modernite ve Batılılaşmanın birbirinin aynısı olmadığını savunur: "modernitenin batılı örnekleri 'otantik moderniteler' değildir, hatta tarihi olarak diğer çağdaş tasarıların öncesindedir ve onlar için merkezi bir referans noktası olmaya devam ettiler." Shmuel Noah Eisenstadt, "The Reconstruction of Religious Arenas in the Framework of Multiple Modernities", Millennium: Journal of International Studies 29/3, 2000, s. 593.

64 Nurettin Topçu, "Rönesans Hareketleri”, Hareket 1/1 (Şubat 1939), Yarınki Türkiye, s. 73-75. 
Avrupa'da fenalıklar, hastalıklar var, ama bu onun ahlâkı değildir; belki ahlâkının düşmanlarıdır. Avrupa en az yarım asırdan beri bu buhranların pençesinde kıvranıyor ve ..... kurtuluşunun çarelerini arıyor ... Bu medeniyet [Hıristiyan], aşkın eseridir. Rönesans ve romantizm bu aşkın eserleridir. ${ }^{65}$

Bu manada Topçu'nun görüşünde, Hıristiyanlık Batı medeniyetinin oldukça temel ve pozitif kökleri olarak sunulmuştur. Bir ruh ve manevi ihtiyaçlarıyla düşünülen insanoğlu fikri Hıristiyanlık'la dünyaya yayılmıştı. Aslında, bütün ilim ve sanatlar felsefe ve ahlâk gibi bu fikrin eserleriydi. Maalesef, bu Hiristiyan fikri insan türünü makinalara mecbur eden büyük sanayinin ortaya çıkmasıyla on dokuzuncu yüzyılda derin bir ahlâk buhranına dönüşmüştür. ${ }^{66}$ Onun gözünde, çağdaş sanayi medeniyeti ve din arasında böylesine karşıt bir ilişki var olmuştur. Bu manada, Batı'da sanayi medeniyeti ile Hıristiyanlık tarihi arasında gerekli ve mukadder bir ilişki olduğunu düşünmemiş, fakat bundan da öte büyük sanayi hâkimiyetini Hıristiyanlık'ın ruhuna aykırı olarak yorumlamıştır. Dini kaynaklarından ayrılmasıyla Batı medeniyetinin çöküşü kaderi hâline gelmiştir.

Özetlemek gerekirse, Topçu'nun Hıristiyanlık'la ilgili olumlu değerlendirmesi bütün İslamcı modernistlerin Hiristiyanlık fikrinden çok ötedeydi. ${ }^{67}$ Topçu'nun Batı tanımlaması diğer Hıristiyanlar gibi de değildi. Dahası, Hıristiyanlık, İslam'ın paylaştığ 1 ve sanayileşmenin olumsuz etkileri karşısındaki mücadelede manevi bir kaynak olduğu geleneğin bir parçası olarak sunulmuştur. İslam ve Batı'nın medeniyet söylemlerinin ötesinde evrensel insanlık için fikirsel bir çabanın örneği olması adına, Topçu'nun Batı algısı Necip Fazıl'ınkinden ayrı bir konumdadır. 19. yüzyıl İslamcı modernistlerin Hıristiyanlık karşıtı fikirlerinin tersine o, Batı medeniyetini evrensel bir hikâyenin parçası olarak okudu, ahlâk, felsefe ve dinini takdir etti. Topçu'nun sanayi Kapitalizm'i karşıtı Müslüman-Hıristiyan ortaklığı fikrinin bugününkileri de kapsamak üzere seküler Türk aydınları arasında bile eşine rastlanmamıştı.

\section{Batı'nın Olumsuz Yüzü: Sanayileșme}

Topçu'nun bakış açısına göre, insanlık sadece İslam toplumlarını ve değerlerini değil aynı zamanda Hıristiyanlık ve Batı'nın manevi mirasını da zora sokan ahlâki bir buhranla yüz yüzeydi. Bu buhran, iki asır öncesinden beri süren Avrupa'daki sanayileşmenin kaçınılmaz neticesiydi. Bu olumsuz gelişmeler karş1-

65 Nurettin Topçu, “Garbın İlim Zihniyeti ve Ahlak Görüşü”, s. 40-41, 176; Ahlak Nizamı, s. 228; "Millette İzzeti Nefs ve Siyaset", Hareket 2/18, (A ğustos 1948), Iradenin Davası, s. 40.

66 Nurettin Topçu, Kültür ve Medeniyet, s. 175, 199.

67 İslamcı modernist düşünürlerden Abduh gibi Hıristiyanlık için olumsuz değerlendirmelere örnek olarak bkz.: Yvonne Yazbeck Haddad, "Islamist Depictions of Christianity in the Twentieth Century: the Pluralism debate and the depiction of the other", Islam and Christian-Muslim Relations 7/1 (1996), s. 75-93. 
sında mücadele eden Avrupalı akımlar mevcuttu. Pascal'ın aşk ve iman kuvveti, Kant'ın ahlâk1 ve Rousseau'nun tabiat aşk1 ve kalp ahlâkı Hıristiyan ruhunun Avrupa'da yarattığı hareketlerdi. Fakat ne yazık ki, sanayinin zorbalığ [makine istibdadı] ve milliyetçiliğin saptırıcılığ Avrupa emperyalizmi ve iki dünya savaşı olarak sonuç verdi. Avrupa medeniyetinin buhranının tek çözümü maddecilik ve sanayi karşısında ruhî kuvvetlerin, iktisat karşısında ahlâkın hâkimiyetiydi. Avrupa'ya bu kurtuluşu getirecek olan içtimaî sınıf nefsinde madde ve ruh kuvvetlerini birleştiren bir sınıf olabilirdi. ${ }^{68}$ Dahası, büyük sanayinin zorbalığı nedeniyle, kaynaklara dönüş [benliğe dönüş] şeklindeki Romantik fikirden kaynaklanan milliyetçi hareketler yirminci asırda baskın hale gelen emperyalist mantıkla kaçınılmaz şekilde son buldu. ${ }^{69}$

Topçu'ya göre Batı'nın coğrafi ve medeni aslı gerçekten Avrupa'ydı. Onun bakışına göre, Amerikan kültür ve medeniyeti Avrupa medeniyeti mirasına ait değildi ve Amerika'nın teknik hakimiyeti Avrupa medeniyetinin temelini (felsefe, sanat ve edebiyat) yerle bir ediyordu. Böylece, Batı'nın ahlaki çöküşü, ona göre, kesin hakikati reddeden ve faydası [pratik menfaate elverişlilik] nispetince hakikat kavramını görelileştiren Amerikan pragmatizmiyle bağlantılıydı. Teknoloji ve faydacılık tanımıyla Amerikan kültürü bütün din, fikir ve ruh kavramlarına karşı yıkıcıydı. ${ }^{70}$

Topçu'nun sonraki yazılarında Amerika ile ilgili olumsuz değerlendirmeleri 1960'larda Amerika'yı diktatöre gülümseyen, bütün felsefe, tarih ve milli kimliğinden yoksun bir Amerika olarak tanımlama derecesine ulaşmıştı. Bununla beraber hala Avrupa medeniyetini bilimini, sanatını ve felsefesini delil göstererek, dünyanın ruhu için bir odak olarak olumlu bir şekilde tanımlıyordu. Öte yandan İslam kültürü Topçu tarafından yeryüzünde adalet ışığını yayan ve sanayi kapitalizminin yıkıcı güçlerine karşı Avrupa medeniyetinin muhtemel ortağı olarak tanımlanıyordu.

Topçu'nun Soğuk Savaş mücadelesini incelemesi onun Batı medeniyeti ve Amerikan kapitalizmine bakışını yansıtır. Ona göre, Kapitalizm zulmüne tepki olarak doğan anlaşılması güç bir insan hareketi olan Komünizm'in ortaya çıkmas1 ve yükselmesinin sorumlusu Amerikan kapitalizm ve liberalizmidir. Topçu'nun

68 Nurettin Topçu, “Avrupa”, Hareket 1/9 (Şubat 1943), Yarınki Türkiye, s. 165; "İçtimai Sınıflar”, Hareket 1/2 (Mart 1939) ve 1/3 (Nisan 1939), Yarınki Türkiye, s. 220-221.

69 Nurettin Topçu, "Rönesans Hareketleri”, Hareket 1/1 (Şubat 1939), Yarınki Türkiye, 75-6 ve "Avrupa", Hareket 1/9 (Şubat 1943), Yarınki Türkiye, s. 165. Avrupa'daki 1rk fikrinin ilk içtimaî tecrübeleri ve çöküşleriyle ilgili yorumları için bkz.: "Millet ve Milliyet", Hareket 1/2 (Mayıs 1943), Yarınki Türkiye, s. 127.

70 Nurettin Topçu, Türkiye'nin Maarif Davası, İstanbul, Dergâh, 1997, 3. bsk., s. 135-136, “İradenin Davası", Hareket 2/2 (Nisan 1947), Iradenin Davası, s. 20; "Mesuliyet Hareketi”, Hareket 3/1 (Aralık 1952), Yarınki Türkiye, s. 198. 
Yahudi finans gücü ve faydacılığına ${ }^{71}$ dayanan Amerika alg1s1 Kısakürek'in Yahudi karşıtı fikirlerine benzemektedir. Topçu, Soğuk Savaş dönemi boyunca yazdığ dünyanın iki süper gücü Amerika ve Rusya'yı tartıştığ yazılarda ruha karşı madde/teknolojinin üstün hâle gelmesi karşısında insanlığın kurtuluşunu aradı ve her ikisinin de talihi karanlıktı. ${ }^{72}$ Komünizm karşıtı mücadele, ona göre, İslam ve Hıristiyanlık'ın işbirliğiyle sürdürülmek zorundaydı, çünkü bu mücadele materyalist güçler karşısında maneviyatın bir savaşıydı. ${ }^{73}$

Necip Fazıl'ın Doğu enternasyonalizmi fikrinden ayrılarak, Topçu, Anadolu Müslüman tecrübesine dayalı milliyetçi bir İslam fikrini savunmuştur. Doğu bazen maneviyatçılığın ve tabiat ve insan ruhuna saygının yeri olarak olumlu bir anlam barındırmaktadır, fakat Topçu açıkça İslam'ın İran ve Şii yorumlarına muhalifken Çin medeniyetiyle ve hatta İslam'in Arap uygulamalarıyla bile ilgilenmiyordu. Öte yandan, Necip Fazıl'a oldukça benzer şekilde Topçu bazen atalet ve tembelliğin yuvası olarak disiplin ve istekten yoksun olan Oryantalist bir Doğu imajına dayanıyordu. ${ }^{74}$ Türkiye' deki Batılılaşma hareketiyle alakalı olarak ve Kemalizm' in bir eleştirisi olarak Topçu'nun Batı imajı son derece olumsuzdur. Bu Batı, medeniyet namına Türklere saldıran, okulları ve ideolojileriyle istila etmek için “acayip yaratıklar"'1yla Anadolu'ya gelen bir yer olarak tasvir edilmekteydi. Belki de Türk Batıcılarının bu Batı tanımı bir manada Avrupalıları barbarlar ve Haçlılar olarak gören genel İslamcı algının bir devamıdır. ${ }^{75}$

Topçu, Alman Romantikleri Herder ve Fichte gibi, Türk milliyetçiliğine zarar veren çokulusçuluğu reddetmektedir. ${ }^{76}$ Çokulusçuluğu reddi ayrıca Namık Kemâl ve Cemaleddin Afgani gibi ilk İslam reformistlerinden bir esinlenmedir. ${ }^{77}$ Yahudi, Mason, Şii ve Komünistlere muhalif tutumu bu şekilde anlaşılabilir. Yahudi karşıtı düşünceleri ile Filistin hakkındaki tutumu bir arada düşünüldüğünde, o,

71 Nurettin Topçu, Ahlak Nizamı, s. 222-3. Topçu Türkiye'nin Amerikanlaşma’ya karşı koymasını Amerika karşıtı Avrupa'nın Hıristiyan dini karşı koyması örneğinden yola çıkarak adlandırdı. Topçu'ya göre Amerika milli bir gurur değil Yahudi sermayesi tarafından bulundu ve bu nedenle resmi ve siyasi terimlere göre milli bir ülke değildir. Devlet ve Demokrasi, İstanbul, Dergâh, 1998, s. 115.

72 Nurettin Topçu, Türkiye'nin Maarif Davası, s. 134; Devlet ve Demokrasi, s. 115.

73 Nurettin Topçu, "Komünizme Karşı Hristiyan Alemiyle Elele Vermeliyiz", Şule, n. 2 (Haziran1962), Ahlak Nizamı, s. 296-298. Komünizm ayrıca Platon'dan Bergson'a kadar Yunanların ve modern Avrupa'nın felsefe geleneğine göre zararlı bulunmuştur. Bkz.: Ahlak Nizamı, s. 250.

74 Nurettin Topçu, Yarınki Türkiye, s. 11-12.

75 Nurettin Topçu, Kültür ve Medeniyet, s. 98; Devlet ve Demokrasi, s. 184; Íslam ve İnsan, s. 100.

76 Milliyetçilik, Hümanizm, Çokulusçuluk ve din konularında Topçu Romantizm'in etkisi altındadir.

77 Namık Kemâl ve Cemaleddin Afgani'nin Çokulusçuluk fikriyle ilgili olarak bkz.: Sami Zubaida, "Cosmopolitanism and the Middle East", Cosmopolitanism, Identity and Authenticity in the Middle East, ed. Roel Meijer, Surrey, Curzon Press, 1999, s. 22-24. 
Yahudileri Komünizm dahil bütün yıkıcı güçlerin temelinde görmektedir. ${ }^{78}$ Onun Yahudi karşıtı düşünceleri 1967 savaşından sonra en üst seviyeye ulaşmıştır, bu aşamada onun için, Yahudiler -Hıristiyanlık’a yönelik olumlu bakışının tam olarak tersine bir genellemeyle, hakikatin ve insanlığın en büyük düşmanları olarakİblis'le bir tutulmuştur. ${ }^{79}$

78 Nurettin Topçu, “Üç Kanlı Parti”, Bizim Türkiye 2, 10 Mart 1948, s. Yarınki Türkiye, 235-238.

$79 \mathrm{Bu}$ tutumla Yahudilerin İslam ülkesinin merkezini, Osmanlı İmparatorluğu'nu ve Fransız ve Bolşevik ihtilallari arkasındaki gücü yıkmaktan sorumlu olduklarını iddia etmiştir. Bkz.: Ahlak Nizamı, s. 178-179, 205-209, 210-211, 212, 214-215. 


\section{Sonuç}

Cumhuriyet döneminin bu iki kilit ismi üzerine yapılan incelemeye dayanarak öncelikle son dönem Osmanlı ile Cumhuriyet dönemi İslamcılıkları arasındaki kopukluğu vurgulamamız gerekmektedir. Birçok şekilde, son dönem Osmanlı İslamcılık'1 enternasyonel, çokulusçu ve Osmanlı İmparatorluğu'na özgü bir bakış açısını benimsemiştir -kendini medeniyetçi modernizm olarak açıklayan-. Onlar, hatırı sayılır bir gayri Müslim nüfusla (Yunanlılar, Ermeniler ve Yahudiler) bir imparatorlukta ortak kaderi paylaşan Müslümanlar hakkında tedirginlerdi. Öte yandan, Cumhuriyet dönemi İslamcıları için en önemli husus etnik ve dini olarak homojen bir Türkiye idealiydi. Nurettin Topçu'nun önceki yazılarında bu nedenle Anadolu'nun Ermeniler ve Yunanlılar için de birkaç asırdır vatan olduğunu tartışmaksızın Anadolu İslam'ından söz etmiş olması muhtemeldir. Topçu ve Kısakürek' in Yahudi karşıtı beyanları da Avrupalı düşünce akımlarıyla Cumhuriyet dönemi ilişkisini yansıtmaktadır ve sön dönem Osmanlı İslam düşüncesinde herhangi bir kökü yoktur. Bunu Kısakürek ve Topçu'nun post-emperyalist oluşları ve milliyetçi-Kemalistlerin bu manada bahsettikleri bu toprakların çokuluslu, çok dinli ve çok ırklı oluşunun ciddi olarak göz ardı edildiği Müslüman Türkiye-Anadolu takip etmektedir.

İslamcı entelektüel düşüncenin dirilişi iki olgunun terkibinden etkilenmiştir: Kemalizm'in köklü Batıcı reformları ve savaş arası yılları boyunca Avrupa'daki entelektüel ve ideolojik hava. Kemalist ve İslamc1 aydınların hepsi İslam'ın ortaçağ yorumunun modern çağların ihtiyaçlarını ve meydan okumalarını tatmin edemeyeceğini düşündüler. Bu kanaatin ardından Kemalist entelijensiya daha ileri gitti ve İslamcılar kamusal alan ve aile içi düzen görüşlerine esas olarak İslam'ın yeni bir yorumunu düşünürken onlar Türkiye'de İslam'ın alanının özel ilgi alanına hapsedilmesi sonucuna vardılar. İslamcı aydınların Batı hakkındaki tutumu Kısakürek ve Topçu'nun çalışmalarında ifadesini buldu. Kısakürek'in siyasi fikirlerinde, özgünlük arayışı Batı karşısında İslam'ın dinî, kültürel ve ahlâkî üstünlüğüne güvenen bir fikrî duyarlılığa yol açtı. Öte yandan Topçu, Batı ya da moderniteyi İslam'la boy ölçüştürmek adına modernite ve sanayileşmeyi tartışmadı.

Topçu ve Kısakürek'in İslam-Batı medeniyeti söylemi dışında, bu inceleme Avrupalı ve Türk aydınların paylaştı̆̆ 1 Batı'nın yükselişi ve Müslüman dünyasının gerileyişi fikirleri çerçevesinde modernite ve tarihî özcülügün özcü hikâyelerinin gücünü göstermektedir. Kısakürek ve Topçu Batı, modernitenin yükselişi ve özellikleri hakkındaki Avrupalı fikirlere oldukça yakındırlar. Onların Batı ya da modernitenin önemli tabiatı hakkındaki argümanları kendi buluşları değildi. Pek çok şekilde, Avrupa ve ötesindeki aydın çevrelerden yayılmış olan fikirlerden üretilen en önemli Batı algılarını yeniden şekillendiriyor ve tazeliyorlardı. Aslında, İnsanlığın tarihî değişiminin en büyük amacı olarak Batı fikrini somutlaştıran, Avrupa'nın modernitenin kökeni konusundaki muzafferane hikâyeleriydi. Ve ço- 
ğunlukla Müslüman öteki ile ilişkili olarak esas Batı fikrini inşa eden, Avrupalı aydınlardı. Kısakürek ve Topçu yaratıcı bir şekilde Avrupa medeniyetinin erdemleri ve zaafları konusunda çeşitli alt-metinlerle yarışan çok zengin bir edebiyata dayandılar. Batı-Özcülüklerinin çeşitlerinin tüm farklılıklarına rağmen Batı'nın var olduğu ve moderniteyi yarattığı hususunda ortak bir görüş vardı. Benzer şekilde, İslam medeniyeti de mevcuttur, fakat küresel modernitenin belirmesiyle onu reddetmiştir ve yapacak bir şeyi kalmamıştır. Kısacası, küresel modernitenin kökenleri hakkındaki Avrupa-merkezci hikâyeler, İslam-Batı medeniyet söylemi ile, Topçu ve Kısakürek'in İslamcılık için sundukları temel şablonlarla ikiye katlanmıştır.

Yine de, Kısakürek ve Topçu'yu geleneksel İslam medeniyetini dışarıdaki öteki Batı karşısında boy ölçüştüren tamamen farklı bir okulun sözcüleri olarak değerlendirmemeliyiz. Onlar Batı medeniyetinin gerilemesi ve buhranı konusundaki Avrupa içi tartışmalara bir hayli dâhildiler. Aslında, biri iyi biri kötü olarak Hıristiyanl1k'1 işaret eden; biri teknoloji ve sanayiyi olumlu olarak gören, diğeri Batı medeniyetinin asıl ruhunun yıkıcısı olarak tanımlayarak bu tartışmada karşıt taraflarda yer almışlardır. Eğer Kısakürek ve Topçu Fransızca yazan Fransız aydınlar olsaydı, 1930'lardan 1950'lere kadar çoğu Avrupa düşüncesi alanından birine dâhil olacaklardı. Aslında Topçu birtakım fikirlerini anlaşılması pek kolay olmayan felsefe doktora tezinde orijinal olarak Fransızca kaleme almıştır. Fakat Türkiye'de ve Türkçe yazarken Topçu ve Kısakürek modernite buhranına bir çözüm olarak sundukları görüşlerinde İslam-Batı medeniyet terkibini kurgulamışlardır. Bu farklı düşünce katmanı hala Oryantalizm ve modernitenin Avrupa-merkezci hikâyelerine dayanmaktadır, fakat Topçu, Kısakürek ve diğer İslamcıların "hakiki" İslam modernitesini yeniden şekillendirme girişimlerinin sonucu olarak fikirlerinin ve değerlerinin yeni bir sunumunu vermektedir.

Çoklu-özcülükler arasındaki mücadelede, Avrupalı modernist hikâyeleri, İslamcıların ya da diğer ideolojik akımlarınkiler kadar suçludur. Bu, belki de Kısakürek ve Topçu neslinden elde edilecek gerçek derstir. Mecvut Türk ve Avrupalı aydın nesli için özcülükten kaçınmanın en iyi yolunu anlamak küresel modernite tarihinin daha doğru ve daha az Avrupa-merkezci - Batı karşısında İslam mantığı tuzağına düşmeyen- bakış açısını teşvik etmekten geçmektedir. 


\section{Kaynakça}

Algar, Hamid, "The Naqshbandi Order in Republican Turkey," Islamic World Report, 1/3, 1996.

Altun, Fahrettin, “Alternatif Tarih Yazmak: Necip Fazıl Kısakürek’in Hafiza Siyaseti," Toplum ve Bilim, 123, 2012.

Anahatlarıyla İlk Necip Fazıl Kısakürek Biyografisi, İstanbul, Büyük Doğu, 2000 .

Aydın, Ertan, "Peculiarities of Turkish Revolutionary Ideology in the 1930s: The Ülkü Version of Kemalism, 1933-1936", Middle Eastern Studies 40, no. 5, 2004.

Carrier, James G., "Introduction", Occidentalism: Images of the West, ed. James G. Carrier, Oxford, Clarendon Press, 1995.

Çetinsaya, Gökhan, "Rethinking Nationalism and Islam: Some Preliminary Notes On the Rrots of Turkish-Islamic Synthesis in Modern Turkish Political Thought," The Muslim World LXXXIX/3-4, July-October 1999.

Duran, Burhanettin, "Transformation of Islamist Political Thought in Turkey From the Empire to the Early Republic (1908-1960)", (Yayımlanmamış Doktora Tezi), Bilkent Üniversitesi, Ankara, 2001.

Eisenstadt, Shmuel Noah, "The Reconstruction of Religious Arenas in the Framework of Multiple Modernities", Millennium: Journal of International Studies, 29/3, 2000.

Euben, Roxane, Enemy in the Mirror, Princeton University Press, 1999.

Eyerman, Ron, Between Culture and Politics: Intellectuals in Modern Society, Cambridge, Polity Press, 1994.

Gümüşhanevi Ahmed Ziyaüddin: Hayatı-Eserleri-Tarikat Anlayışı ve Halidiyye Tarikatı, İstanbul, Seha, 1984.

Haddad, Yvonne Yazbeck, "Islamist Depictions of Christianity in the Twentieth Century: the Pluralism debate and the depiction of the other", Islam and Christian-Muslim Relations, 7/1, 1996.

Hay, Stephen N., Asian Ideas of East and West: Tagore and His Critics in Japan, China, and India, Harvard University Press, 1970.

Horkheimer, Max - Adorno,Theodor, Dialectic of Enlightenment, Standford University Press, 1944, 2007.

Kısakürek, Necip Fazıl, “Asyacılık-Avrupacılık”, Büyük Doğu 1. yıl, 2/29, 17 Mayıs 1946. İstanbul, Büyük Doğu, 1998. 
1952.

, “Batı'nın Doğu'ya Bakışı”, Büyük Doğu 2. yı1, n. 15, 30 Mayıs

, "Batının Buhranı", Büyük Doğu 1. yı1, 1/19, 19 Kasım 1943; Büyük Doğu, n. 11, 19 Haziran 1959.

Ekim 1967.

, “Batının İki Yüzü”, Büyük Doğu 24. y11, 13. periyot, n. 19, 22

, "Batının Kendisine Bakışı”, Büyük Doğu 12. periyot, n. 16, 5 Ocak 1966.

, "Batının Kendisine”, Büyük Doğu 1. yı1, 1/4 , 23 Kasım 1945.

, "Batının Ucuzculuğu”, Büyük Doğu n. 4, 28 Mayıs 1954.

, "Buhranımızın Kundakçısı Yahudi”, 27 Haziran 1980; Rapor 10/13, 2. bs., İstanbul, Büyük Doğu, 1993. ziran 1952.

, "Doğunun Kendisine Bakıșı”, Büyük Doğu 9. yı1, n. 36, 20 Ha-

, “Doğunun Mizanı”, Büyük Doğu 1. y11, 1/5, 15 Ekim 1943.

, "Doğunun Ucuzculuğu”, Büyük Doğu. n. 3, 21 Mayıs 1954.

, "Doğuya İnanalım”, Büyük Doğu 9. yıl, n. 41, 27 Haziran 1952.

, "Faşizma", 23 Mart 1939; Çerçeve 1, 3. bs., İstanbul, Büyük

Doğu, 1998.

1967.

, “İki Ejderha”, Büyük Doğu 24. yı1, 13. periyot, n. 18, 15 Kasım

, "Kendi İçinde Batı", Büyük Doğu, n. 6, 22 Ekim 1943 ; Büyük Doğu, n. 69, 25 Temmuz 1952.

, "Kendi İçinde Doğu”, Büyük Doğu 9. y1l, n. 62, 18 Temmuz 1952 ; Büyük Doğu, n. 11, 15 May1s 1959.

, “Komünizma”, Büyük Doğu 14. periyot, n. 3, Temmuz 1969.

, "Moskof", Büyük Doğu, 28. y11, 15. periyot, n. 10, 10 Mart

1971.

, “Tarihi Vade", Büyük Doğu 9. y11, n. 103, Ağustos 28, 1952.

, Başmakalelerim 1, İstanbul, Büyük Doğu, 2013.

, Başmakalelerim 3, İstanbul, Büyük Doğu, 1995.

, Batı Tefekkürü ve İslam Tasavvufu, 2. bs., İstanbul, Büyük

Doğu, 1984.

, Çepçevre Sosyalizm, Komünizm ve İnsanlı, 2. bs., İstanbul, Büyük Doğu, 1985. 
, Doğru Yolun Sapık Kolları, 7. bs., İstanbul, Büyük Doğu, 1996. , Dünya Bir İnklâp Bekliyor, 3. bs., İstanbul, Büyük Doğu, 1993. , Hitabeler, 2. bs., İstanbul, Büyük Doğu, 1985. , İhtilal, İstanbul, 6. bs., Büyük Doğu, 1997. , Konuşmalar, 2. bs., İstanbul, Büyük Doğu, 1994. , Sahte Kahramanlar, 4. bs., İstanbul, Büyük Doğu, 1987. , Yeniçeri, 2. bs., İstanbul, Büyük Doğu, 1977.

Lindstrom, Lamont, "Cargoism and Occidentalism", Occidentalism: Images of the West, ed. James G. Carrier, Oxford, Clarendon Press, 1995.

Mardin, Şerif, "Religion and Politics in Modern Turkey", Islam in the Political Process, ed. James P. Piscatori, Cambridge, Cambridge University Press, 1983. , Din ve İdeoloji, 5. bs., İstanbul, İletişim, 1992.

_, Türkiye'de Din ve Siyaset, 2. bs., İstanbul, İletişim, 1992.

Okay, M. Orhan, Necip Fazıl Kısakürek, İstanbul, Şule, 1998.

Ögün, Süleyman Seyfi, Türkiye'de Cemaatçi Milliyetçilik ve Nurettin Topçu, İstanbul, Dergâh, 1992

Reed, Howard A., "The Religious Life of Modern Turkish Muslims", Islam and the West, ed. Richard N. Frye, The Hague, Mouton\& Co, 1956.

Shils, Edward, "Intellectuals", International Encyclopedia of the Social Sciences, New York, Macmillan, 1968.

, "The Intellectuals in the Political Development of the New States", Political Development and Social Change, eds. Jason L. Finkle and Richard W. Gable, New York, John Wiley and Sons Inc, 1971.

Siddiqi, Mazheruddin, Modern Reformist Thought in the Muslim World, Delhi, Adam Publishers and Distributers, 1993.

Sorokin, Pitirim A., The Crisis of Our Age, Oxford, Oneworld, 1941, 1992.

Topçu, Nurettin, "İradenin Davası”, Hareket 2/2, Nisan 1947.

, “Ahlak Nizam1," Hareket 2/1, Mart 1947.

, “Avrupa”, Hareket 1/9, Şubat 1943.

, "Benliğimiz”, Hareket 1/4, Mayıs 1939.

, "Bizde Milliyet Hareketleri”, Hareket 1/3, Nisan 1939.

, “Din Hayatı”, Komünizme Karşı Mücadele, 36, 15 Mayıs 1952.

, "Eşitlik Davası", Komünizme Karşı Mücadele, 22, 15 Haziran 
, “Garbın İlim Zihniyeti ve Ahlak Görüşü”, 1955.

, "İçtimai Sınıflar”, Hareket 1/2, Mart 1939; 1/3, Nisan 1939.

Şule, 2, Haziran 1962.

"Komünizme Karşı Hristiyan Alemiyle Elele Vermeliyiz",

, "Mesuliyet Hareketi”, Hareket 3/1, Aralık 1952.

, "Millet ve Milliyet", Hareket 1/2, May1s 1943.

, "Millette İzzeti Nefs ve Siyaset", Hareket 2/18, Ağustos 1948.

, "Rönesans Hareketleri”, Hareket 1/1, Şubat 1939.

, “Üç Kanlı Parti”, Bizim Türkiye, 2, 10 Mart 1948.

, Ahlak Nizamı, 3. bs., İstanbul, Dergâh, 1997.

, Devlet ve Demokrasi, İstanbul, Dergâh, 1998.

, Iradenin Davası, İstanbul, Dergâh, 1998.

, İslam ve Insan, İstanbul, Dergâh, 1998.

, İsyan Ahlakl, İstanbul, Dergâh, 1995.

, Kültür ve Medeniyet, 5. bs., İstanbul, Dergâh, 2010.

, Mehmet Akif, 2. bs., İstanbul, Dergâh, 1998.

, Mevlana ve Tasavvuf, İstanbul, Dergâh, 1998.

, Türkiye'nin Maarif Davası, 3. bs., İstanbul, Dergâh, 1997.

, Yarınki Türkiye, 4. bs., İstanbul, Dergâh, 1997.

Toprak, Binnaz, "Islamist Intellectuals: Revolt Against Industry and Technology", Turkey and the West: Changing Political and Cultural Identities, ed. Metin Heper, Ayşe Öncü, Heinz Kramer, London, I. B. Tauris, 1993.

Zubaida, Sami, "Cosmopolitanism and the Middle East", Cosmopolitanism, Identity and Authenticity in the Middle East, ed. Roel Meijer, Surrey, Curzon Press, 1999. 
